\title{
A Magyarországi paleogén medence paleo-oceanográfiája bentosz foraminiferák paleoökológiai vizsgálata alapján
}

\author{
OZSVÁRT Péter ${ }^{1}$ \\ ${ }^{1}$ MTA-MTM-ELTE, Paleontológiai Kutatócsoport, 1431 Budapest Pf. 137. \\ e-mail: ozsvart.peter@nhmus.hu
}

\section{Palaeocanographic history of the Hungarian Palaeogene Basin using a palaeoecological analyis of benthic foraminifera}

Abstract

16 late Palaeogene (Lutetian-Rupelian) boreholes and sections from the Hungarian Palaeogene Basin were investigated for their benthic foraminiferal faunas in order to reconstruct its palaeoecological and palaeoceanographic evolution. In the mentioned ecological interpretation of the temporal distribution of foraminiferal assemblages, multivariate statistical methods were used. These methods included Q-mode principal factor analysis (PFA) and BFOI (Benthic Foraminiferal Oxygen Index) analysis. On the basis of the Q-mode principal factor analysis, the faunas are characteristic for inner neritic (0-30 m water depth) to upper bathyal environments (approximately $30-500 \mathrm{~m}$ water depth). The composition of the benthic foraminiferal fauna and the results of the Q-mode principal factor analysis indicate tropical-warm conditions from the beginning of the Middle Eocene. A change in the temperature of the bottom water can be detected from the late Middle Eocene time, and estimated temperatures indicate temperate-cold conditions during this period. On the basis of the BFOI (Benthic Foraminiferal Oxygen Index) analysis, the Middle and Late Eocene are characterised by two short eutrophic events $\left(\mathrm{POMZ}_{1}\right.$ and $\left.\mathrm{POMZ}_{3}\right)$ and two significant eutrophic $\left(\mathrm{POMZ}_{2}\right.$ and $\mathrm{POMZ}_{4}$ ) events. These periods are characterised by evidence of a low diversity of fauna, with a high dominance of lowoxygen tolerant (infaunal) species. The eutrophic events suggest that there was a second-order sea-level fall and restricted deep water circulation, while the oligotrophic and high oxic conditions might have been caused by colder, welloxygenated bottom water masses from the SE Tethyan Realm. Evidence suggests that these oligo- to mesotrophic periods were characterised by a high diversity of fauna, with a signifcant dominance of epifaunal species. The initial stage of the significant subsidence history coincides with the POMZ 2 period at the end of the NP17 zone. This demonstrates clearly that the evolution of the Hungarian Palaeogene Basin was strongly influenced by significant palaeoceanographic events.

Keywords: palaeoceanography, benthic foraminifera, Palaeogene, palaeoecology

Összefoglalás

A Magyarországi paleogén medence különböző részmedencéiből 14 mélyfúrás és két felszíni szelvény felső-paleogén rétegsorának bentosz foraminifera faunáját vizsgáltam. A foraminifera közösségek statisztikai elemzéséből részletes, a paleoökológiai és a paleo-oceanográfiai változásokat jól dokumentáló adatsorokat kaptam. Ezek elemzéséből rekonstruálni tudtam a legfontosabb oceanológiai paramétereket: az egykori sótartalmat, a hőmérsékletet, a vízmélységet, valamint a szervesanyag fluxust. A folyamatos és közel ekvidisztáns mintavételezés alapján a sokváltozós statisztikai módszerek segítségével az említett paraméterek időbeli változását is meghatároztam. Megállapítottam, hogy a középsőés késő-eocén folyamán képződött üledékek a bentosz foraminiferák paleoökológiai elemzése alapján a kontinentális self sekély litorális övétôl (5-30 méter), a szublitorális-mélyszublitorális övön keresztül (30-200 méter), a batiális öv felsố részéig (200-500 méter) rakódhattak le. A foraminifera közösségek domináns fajai alapján a középső-eocén elejétől a bakonyi területen kialakult medencében fokozatos hőmérséklet-csökkenés feltételezhetô. A különböző területeken az időben eltolódó lehűlés a topográfiai különbségeknek köszönhető. A középső- és késô-eocén folyamán az inbentosz és az epibentosz közösségek statisztikai elemzéséből két gyengébb ( $\mathrm{POMZ}_{1}$ és $\left.\mathrm{POMZ}_{3}\right)$ és két jelentôs $\left(\mathrm{POMZ}_{2}\right.$ és $\left.\mathrm{POMZ}_{4}\right)$ eutrofizációs folyamat feltételezhető. A paleogén medence korábban feltételezett, helyenként szélsőségesen gyors ütemú süllyedésének kezdete egybeesik az NP17 zónában kimutatott jelentős eutrofizációs folyamat megindulásával $\left(\mathrm{POMZ}_{2}\right)$, ami így nem egy döntően tektonikai, hanem egy markáns paleo-oceanográfiai eseménynek is tekinthetô.

Tárgyszavak: paleo-oceanográfia, bentosz foraminifera, paleogén, paleoökológia 


\section{Bevezetés}

A Tethys késő-krétától folyamatosan megszúnő kapcsolata a világóceánnal jelentôs változáson ment keresztül a paleogén folyamán. Nyugati övében, az Alpok-KárpátokDinaridák területén, térben könnyen elkülöníthetô és képződési körülményeikben is különböző részmedencék jöttek létre. Az ezekben megôrződött bentosz foraminifera közösségek kitúnően dokumentálták az egykori paleo-oceanográfiai és klimatológiai változásokat. A ma élő bentosz foraminiferák ökológiai igénye alapján, valamint a statisztikai elemzésekből következtetni lehetett a késő-paleogén tenger fizikai paramétereire: az átvilágítottságra, a tápanyag-ellátottságra, a hómérsékletre, a sótartalomra, az áramlási viszonyokra, a vízmélységre, a szervesanyag-fluxusra valamint az oldottoxigén-tartalomra. Dolgozatom legfőbb célja a Magyarországi paleogén medence paleo-oceanográfiai vizsgálata és fejlődéstörténetének értelmezése volt.

\section{A Tethys nyugati területének paleogén medencéi}

Az Alpok-Kárpátok-Dinaridák és a Pannon-térség paleogén medencéit (1. ábra) hagyományosan két csoportba szokták sorolni. Az egyikbe a sekélytengerekben, illetve kontinentális peremek selfjein kialakult ún. „epikontinen- tális" medencék tartoznak (NAGYMAROSY 1990a, b), míg a másikba a mélyebb tengerekben lerakódott, elsősorban sziliciklasztos, törmelékes üledékekkel kitöltött ún. „flis-” övek. A klasszikus értelmezés szerint az elsőbe a Szlovéniai, a Belső-Kárpáti-, az Erdélyi valamint a Magyarországi paleogén medencéket sorolják. Az utóbbiba az AlpokKárpátok-Dinaridák flis öveit: Magura flis öv, Belső-kárpáti flis (vagy Podhale flis medence), a Rhenodanubiai flis öv, a Szolnok-Máramarosi flis medencék (NAGYMAROSY 1990a) valamint a Külsô- és Belsô-Dinári flis övek tartoznak (1. ábra). Jelenlegi térbeli elhelyezkedésük elsősorban a neogén tektonikai folyamatok hatását tükrözi, így a különböző képződmények mai elterjedésének kevés köze van az eocén ôsföldrajzi viszonyokhoz. A Magyarországi paleogén medence kialakulásának nagyszerkezeti okairól jóval kevesebbet tudunk, mint a neogén Pannon-medence geodinamikájáról, amelynek szerkezetfejlődése ma már jól ismert (lásd ROYDEN \& HORVÁTH 1988, TARI 1994 stb.).

\section{A vizsgált terület földtani felépítése és sztratigráfiája}

A Magyarországi paleogén medencében az eocén képződmények jelenlegi elterjedése a középhegység csapásirá-

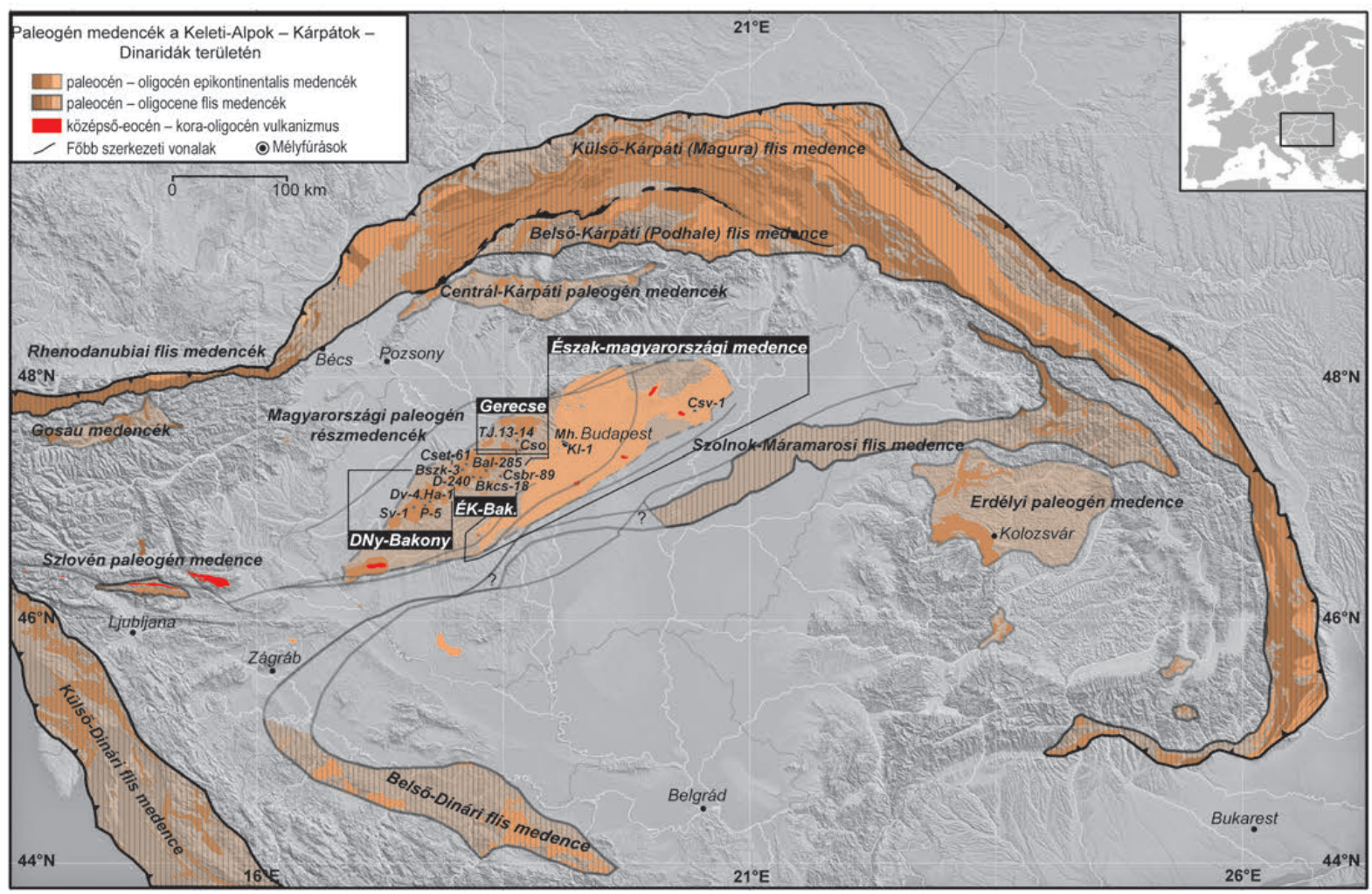

1. ábra. Paleogén epikontinentális és flis medencék az Alpok-Kárpátok-Dinaridák területén, OzsvárT et al. 2016 alapján. $1=$ Somlóvásárhely-1, $2=$ Padrag-5, 3 = Devecser-4, 4 = Halimba-1, ÉK-Bak. = ÉK-bakonyi-vértesi terület, $5=$ Dudar-240, 6 = Bakonyszentkirály-3, $7=$ Csetény-61, $8=$ Balinka-285, 9 = Csákberény-89, 10 = Bakonycsernye-18, 11 = Tarján-12, 12 = Tarján-14, 13 = Csordakúti külfejtés, 14 = Mátyás-hegy keleti köfejtő, $15=$ Kiscell-1, 16 = Cserépváralja -1

Figure 1. Palaeogene epicontinental and flysch basins in the Eastern Alpine-Carpathian-Northern Dinarides junction, after Ozsvárt et al. $2016.1=$ Somlóvásárhely-1, $2=$ Padrag-5, $3=$ Devecser-4, $4=$ Halimba-1, ÉK-Bak. $=$ NE part of Bakony-Vértes, $5=$ Dudar-240, $6=$ Bakonyszentkirály-3, $7=$ Csetény-61, 8=Balinka-285, 9=Csákberény-89, 10 = Bakonycsernye-18, $11=$ Tarján-13, 12 = Tarján-14, $13=$ Csordakút quarry, 14 = Mátyás-hegy Quarry, $15=$ Kiscell-1, $16=$ Cserépváralja -1 
nyával közel párhuzamos, DNy-ÉK-i elrendeződést mutat (1. ábra). A képződmények az idősebb mezozoos aljzatra térben változó nagyságú üledékhézaggal valamint eróziós és szögdiszkordanciával települnek. Ezek alapján két kifejlődési övbe sorolhatók: Bakonyi és Észak-magyarországi kifejlódés. Ezen belül a krono- és litosztatigráfiai, valamint szerkezeti különbségek további osztályozást tesznek lehetôvé (lásd lejjebb). A paleogén medence sztratigráfiáját HoRváTHKollányi (1983), BÁldi-BeKe (1984), NAGYMARosy \& BÁLDI-BeKE (1988) munkái alapján foglaltam össze a 2. ábrán. A litosztratigráfiai egységeket bio- és magnetosztratigráfiai eredmények segítségével korolták (HoRVÁTHKOLLÁNYI 1983; BERNHARDT et al. 1988). A biozonáció nannoplankton (BÁLDI-BEKE 1984) és plankton foraminifera (HoRváTH-KolláNYI 1983, KolLÁNYI et al. 2003) vizsgálatok alapján készült (2. ábra). markáns szerkezetbeli és aljzat különbségek indokolják a további felosztást.

\section{DNy-bakonyi terület}

A DNy-bakonyi terület térbeli elhelyezkedése a SümegHalimba-Devecser-Bakonybél által határolt térségre esik (1. ábra). A transzgressziós bázisképződmény 0-30 méter vastag durvatörmelék, konglomerátum, helyenként szeneshuminites agyagot, szénzsinórokat tartalmaz (Dorogi Formáció). Az egyenletes süllyedés következtében (Vörös 1989) sekélytengeri mészkőplatform (Szóci Mészkő Formáció) alakult ki a medenceperemen. A platform épülése a lutetiai végéig (NP16) mutatható ki, ezt követően szerkezeti (gyors süllyedés), illetve oceanológiai (megváltozott szervesanyagfluxus) hatások következtében hirtelen abbamaradt. Fölfelé folyamatos átmenetként először mészmárgák majd márgák

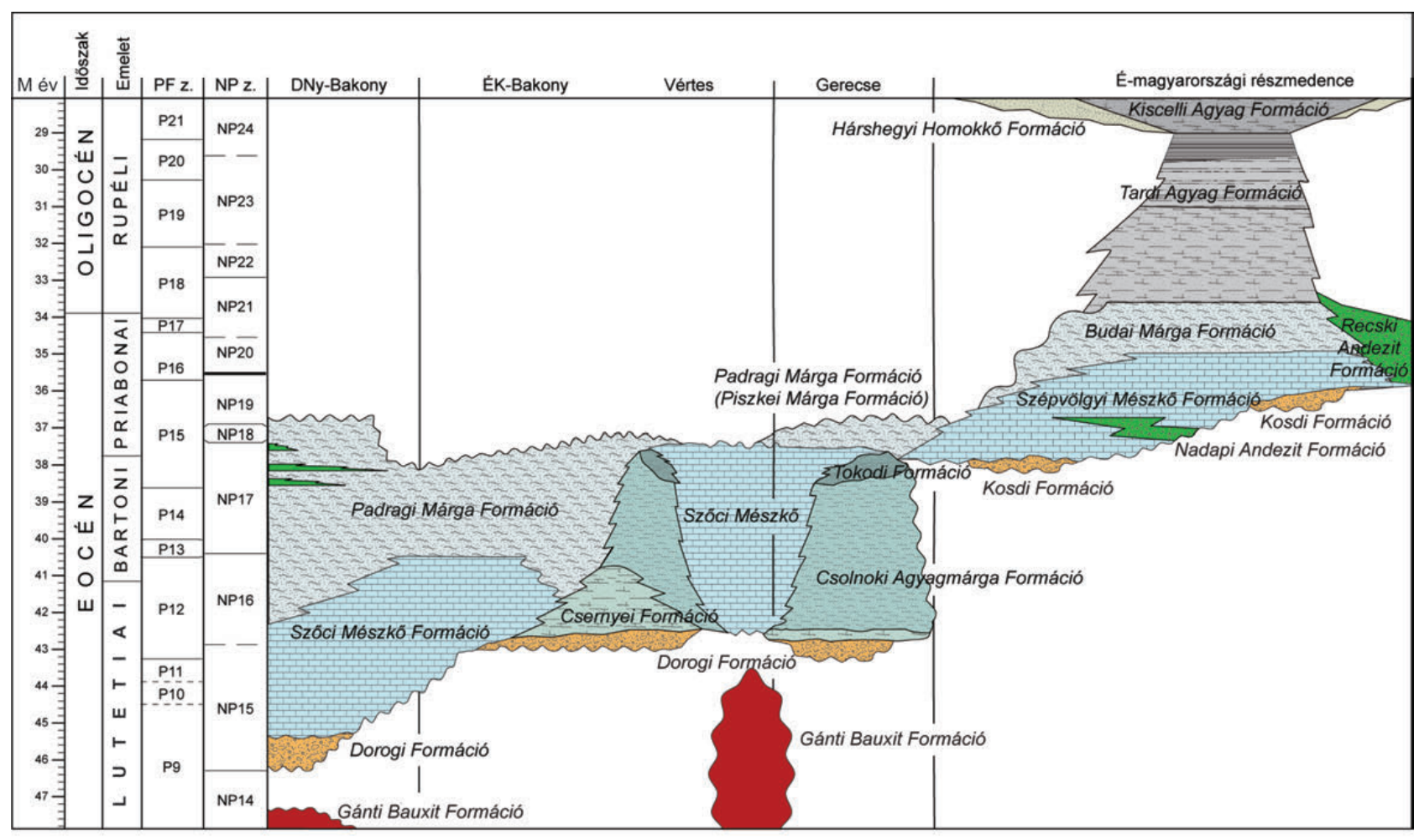

2. ábra. A Magyarországi paleogén medence litosztratigráfiája (KERCSMÁR et al. 2015 alapján)

Figure 2. Litostratigraphy of the Hungarian Palaeogene Basin (after KERCSMÁR et al. 2015)

\section{Bakonyi részmedence}

A Bakonyi részmedencében az üledékképződés a lutetiai elején (NP14) kezdődött (BÁLDI-BEKE 1984). Ez a Bakony délnyugati részére, ill. a felszín alatt a Zala-medencére korlátozódott, ami indokolhatja a Délnyugat-bakonyi kifejlódés elkülönítését. Ezt tovább erôsíti az a tény, hogy az ÉK-i Bakonyban, a Vértesben, valamint a gerecsei területen az üledékképződés csak a lutetiai végén (NP16) kezdődik (BáLDIBEKE 1984), ami jelentôs, minimum 5 millió éves időkülönbséget jelent. A fentiek alapján elkülöníthetô a bakonyi fáciesövön belül az ÉK-bakonyi-vértesi terület valamint a Gerecsei terület is. Ez utóbbiak közötti kifejlődés- valamint
(Padragi Márga Formáció) váltották a karbonátokat. BÁLDIBeke 1984, Horváth-Kollányi \& Nagy-Gellai 1989, BÁLDI-BEKE \& BÁLDI 1991 batiális (800-1200 méteres) mélységet becsültek a márga képződési környezetére. Biosztratigráfiai adatokkal az NP19 nannoplankton zóna mutatható ki, ennél fiatalabb nem, ami feltételezhetően a koraoligocén erózió (TELEGDI-Roth 1927) következménye. A területról a Halimba-1, Devecser-4, Padrag-5 és a Somlóvásárhely-1 fúrások bentosz foraminifera anyagát vizsgáltam.

\section{ÉK-bakonyi-vértesi terület}

Az ÉK-bakonyi-vértesi terület a Zirc-Bakonyszentkirály-Gánt-Balinka-Eplény által határolt térségre esik ( 1 . 
ábra). A bázisképződmény ezen a területen is alluviálislakusztris kifejlődésú széntelepes képződmény (Dorogi Formáció). A DNy-bakonyi kifejlődéssel szemben ezen a területen nem épült egységes karbonátplatform, helyette molluscás-korallos-nagy-foraminiferás képződmények (Csernyei Formáció) jelzik a végleges tengerelöntést. További süllyedéssel folytatódott az agyagos, agyagmárgás, márgás képződmények lerakódása (Csolnoki Agyagmárga Formáció). Kisebb, elszigetelt hátakon vékony karbonátos képződmények (karbonátpadok) (Szóci Mészkő Formáció) heteropikus fáciesként megjelennek, azonban egységes nagy kiterjedésû́ karbonátplatform nem épült ki a területen. A Csolnoki Agyagmárga Formáció helyenként összefogazódik a planktondús Padragi Márgával, majd ez utóbbi képződmény a Vértes DK-i előterétől eltekintve uralkodóvá válik. Ez nem zárja ki azt a lehetôséget, hogy ezen a területen is kifejlődött, azonban az utólagos erózió lepusztította. Az ÉK-bakonyi-vértesi területról a Bakonycsernye-18, a Bakonyszentkirály-3, a Balinka-285, a Csetény-61, a Dudar-240 és a Csákberény-89 számú fúrások anyagát vizsgáltam.

\section{Gerecsei kifejlődés}

A Tatabányától Esztergomig, illetve Solymárig terjedő terület esik a Gerecsei kifejlódésbe (1. ábra). Az ÉK-bakonyi-vértesi területtel szemben itt nem tudott kialakulni egységes medence. Kiemelt hátak által elválasztott, kisméretú medencék füzérszerú sorozatát találjuk a területen (BERNHARDT 1984, KERCSMÁr et al. 2006). Ilyen genetikailag is elkülönülő medencék: a Tatabányai-, a Nagyegyházai-, a Csordakúti-, a Tarjáni-, a Dorogi-, a Pilisvörösvári-, a Solymári- stb.

A medencerendszer csapása Ny-K-i irányú. A bázisképződmény (Dorogi Formáció) szenes kifejlődése nagyon változatos vastagságú, jelezve, hogy a süllyedés üteme eltérô volt. Ezen a területen sem tudott kiépülni egységes karbonátplatform, helyette izolált karbonátpadok fejlődtek ki a kiemeltebb hátakon. A köztes medencékben meszes, márgás, néhol homokos képződmények rakódtak le (Csernyei Formáció) majd itt is az agyagos, márgás képződmények lerakódása következett (Csolnoki Formáció). A márgás kifejlődésbe idônként 10-50 m vastagságú folyóvízi eredetú homok, meszes homokkő padjai (Tokodi Formáció) települnek (BERNHARDT 1984).

A terület északi peremén a késô-eocéntôl (NP18-NP19) kezdődően batiális márgák (Padragi Márga - korábban Piszkei Márga) képződtek (BÁLDI-BEKE 1984). HANTKEN (1871) a Kiscelli Agyag foraminiferáival azonosította a területen kibukkanó márgás összlet bentosz foraminiferáit, míg Vogl (1910) a Budai Márga bryozoás tagozatához hasonlította. A rétegsor felsô részén, tektonikai aktivitás által kiváltott, tömegmozgásos üledékképződés folyt (SZTANÓ \& FODOR 1997) valószínúleg a self előtti mélyebb lejtôn létrejött olisztolitokkal (LESS 1987). A gerecsei területről a Tarján-13 és Tarján-14 fúrásokat valamint a felhagyott csordakúti bauxit külfejtés fedôrétegsorának bentosz foraminifera faunáját vizsgáltam részletesen.

\section{Észak-magyarországi részmedence}

Az Észak-magyarországi részmedence (1. ábra) térbeli elhelyezkedése a Balatonbozsok - Úrhida - Budai-hegység - Duna-balparti rögök - Cserhát - Mátra - Bükk déli pereme területére esik. ÉNy-i határa a Csillaghegy-ÓbudaBudaörs vonal (Budai-vonal), ami viszonylag könnyen kirajzolható. DK-i elterjedési határát a Közép-magyarországivetôzóna elmetszi, ezért folytatása a Szlovéniai paleogén medencében feltételezhetô (NAGYMARosy 1990). Az üledékképződés megindulása a legnyugatibb területektôl eltekintve (Balatonbozsok, Úrhida), ahol már az NP17 nannoplankton zóna legvégére tehető, egységesen a késő-eocén eleje (NP18). A bázisrétegek általában alapkonglomerátummal kezdődnek, amely fölfelé sekélytengeri nummulitesesdiscocyclinás-lithothamniumos mészkőbe megy át (Szépvölgyi Mészkó Formáció). Néhány területen (Balatonfő, Kosd) szenes-huminites rétegeket is tartalmazó, agyagos, felső részén helyenként molluscás, márgás (Kosdi Formáció) képződmény alkotja a bázistagot. A süllyedés folytatódásával kialakult egy mészkőplatform, azonban viszonylag rövid idő alatt megfulladva a biogén mészkőösszlet üledékfolytonossággal a kimélyülést jelző Budai Márgába megy át. Feltételezhetô, hogy az üledékképződést a késôeocén végére a Gerecsei területhez hasonlóan, erôsen befolyásolta a tektonikai aktivitás (FoDOR et al. 1994), ugyanis a márgában 0,5-1 m vastag mészturbidites padok jelentek meg a Budai-hegység területén (BODA \& MONOSTORI, 1972, 1973; VARga 1985). A kora-oligocéntól a Budai Márga folyamatos átmenettel, a makroszkóposan gyakorlatilag elkülöníthetetlen Tardi Agyagba megy át (kivétel ez alól a fiatalabb, lemezes, sötét színú felső része), azt pedig szintén folyamatosan a Kiscelli Agyag Formáció követi (BÁLDI 1983). Az Észak-magyarországi területról a Mátyás-hegyi klasszikus felső-eocén rétegsort valamint a Kiscell-1 és a Cserépváralja-1 fúrások bentosz foraminifera faunáját vizsgáltam.

\section{Vizsgálati módszerek}

A fúrási anyag mintái a Magyar Bányászati és Földtani Szolgálat gyújteményébôl származnak. A szolgálat a mélyfúrások bentosz foraminifera anyagát vizsgálatra előkészítve, az üledékszemcséktôl szeparálva bocsátotta rendelkezésemre, kivéve a Csetény-61, Cserépváralja-1 és Kiscell-1 fúrásokat, valamint a felszíni szelvényeket. Ezeket saját magam mintáztam és néhány napos hidrogén-peroxidos áztatás után a hagyományos iszapolási eljárással nyertem ki mintánként a hozzávetôleg 200 egyedet. Első lépésként meghatároztam az egyes mintákban megtalálható összes fajt, majd ezt követôen a statisztikai vizsgálatokhoz az egyes fajok egyedszámát számoltam meg. A Somlóvásárhely-1 számú fúrás esetében a fajok határozásnál figyelembe vettem KoLLÁNYI Katalin eddig nem publikált és a rendelkezésemre bocsátott eredményeit, ami nagyban megkönnyítette a munkámat. 


\section{Statisztikai módszerek}

A bentosz foraminifera faunák ökológiai értékelését egyváltozós és sokváltozós adatelemző módszerrel végeztem. A sokváltozós adatelemző módszerek esetében a hagyományos ökológiai vizsgálatokkal szemben, itt egyegy mintavételi egységet a bennük található különböző fajokkal, mint változókkal jellemzünk. Mivel nekünk egy fauna időbeli változását kell nyomon követnünk, ezért a változók (fajok) kapcsolatrendszerét kell feltárni olyan matematikai eljárás segítségével, amelynek elsődleges feladata ennek a sok dimenziónak a hatékony redukciója, vagyis a sok dimenzió behelyettesítése kevés számú, de az eredeti adatstruktúrát jól reprezentáló dimenzióval.

A matematikai eljárással történó hatékony dimenziócsökkentés egyik legfontosabb módszere a fófaktor-analízis, amely valójában a fókomponens-analízis iteratív alkalmazása a kommunalitások becslésére (PODANI 1997). A

TROX

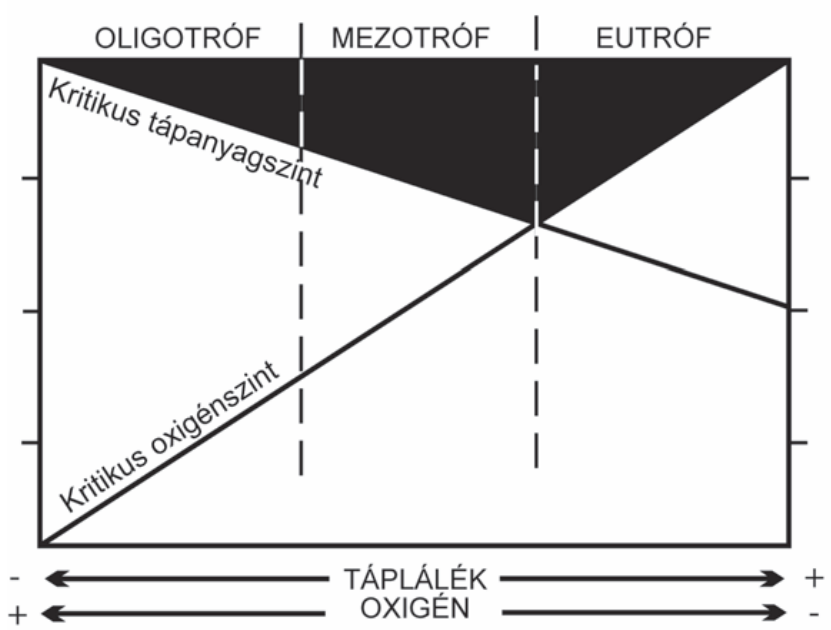

A hatékony dimenziócsökkentést, vagyis a fơkomponens-analízis iteratív alkalmazását a SYSTAT 13.1 statisztikai programcsomaggal végeztem.

\section{Szervesanyag fluxus: TROX és BFOI modell}

Az aljzatra áramló szerves anyag mennyisége, illetve a medence aljzatának oxigén-ellátottsága jól közelíthető az epibentosz és az inbentosz közösségek arányának változásával (CoRLISS \& EMERSON 1990, Jorissen et al. 1995). Az üledék felszínén (epibentosz) és a felszíntől számított 10-15 $\mathrm{cm}$ mélységben (inbentosz) éló foraminifera közösség taxonómiai aránya alapján nem csak a környezet eutrofizációs viszonyaira következethetünk, megbecsülhető az aljzaton áramló tengervíz oldottoxigén-tartalma is. Erre KAIHO (1994, 1999) dolgozta ki az ún. BFOI (Bentosz Foraminifera Oxigén Index) modellt (3. ábra). Az általa javasolt egyenlet:

BFOI

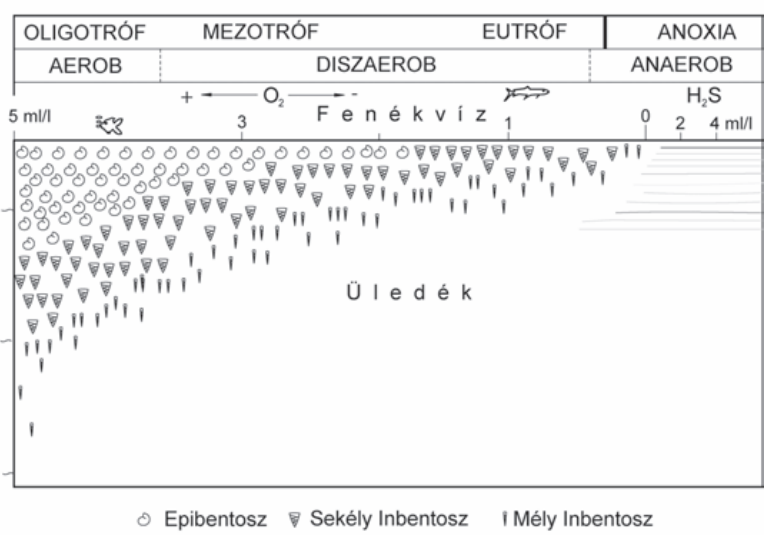

3. ábra. TROX (TRófikus viszonyok és OXigén mennyiség) (JoRISSEN et al. 1995) és BFOI (Bentosz Foraminifera Oxigén Index) modellek (KAIHO 1991) Figure 3. TROX (TRophic condition and OXygen content) (after JORISSEN et al. 1995) and BFOI (Benthic Foraminifera Oxygen Index) models (after KAIHO 1991)

főfaktor analízis legfontosabb elónye, hogy numerikusan lehet értelmezni a kapott eredményeket. Ehhez két adatmátrix szükséges:

$\mathrm{Az}$ első az ún. faktorsúly (varimax factor loading matrix), ami a meghatározott faktorok és a változók közötti korrelációt fejezi ki a teljes rétegsor összes mintájára nézve. Az értéke -1 és 0 valamint 0 és 1 között változhat. Ha az érték nagyobb, mint 0,4 vagy kisebb, mint $-0,4$ a meghatározott faktor és az adott minta között statisztikusan szignifikáns kapcsolatot áll fenn (MALMGREN \& HAQ 1982).

A másik az ún. faktorérték (varimax factor scores matrix), ami az egyes fajoknak a meghatározott faktorokban való „fontosságát” vagyis a faktorértékét fejezi ki. Itt csak a 2-nél nagyobb faktorértékkel rendelkező fajokat vettem figyelembe, mint az egyes faktorokat szignifikánsan determináló domináns és kapcsolódó fajok.

$$
\mathrm{BFOI}=[O(O+D)] \times 100
$$

ahol $O$ a minta epibentosz foraminiferáinak száma (oxifil fajok), $D$ a minta inbentosz foraminiferáinak a száma (suboxikus, dizoxikus fajok). Ha az index értéke 0-50 közötti, akkor a minta inbentosz faunaelemeinek a dominanciája jellemző és ez hozzávetôleg 0,1-3 ml/l oldottoxigént jelent. Ha az index értéke nagyobb, mint 50, akkor a minta epibentosz faunaelemeinek a dominanciája jellemzô és az oldottoxigén mennyisége nagyobb, mint $3 \mathrm{ml} / \mathrm{l}$ (КАIHO 1991, 1999; SCHERBACHER et al. 2001) (4. ábra).

\section{Vizsgálati eredmények}

A vizsgált szelvények foraminifera faunájának taxonómiai és egyváltozós adatelemzéséből kapott eredményeit 


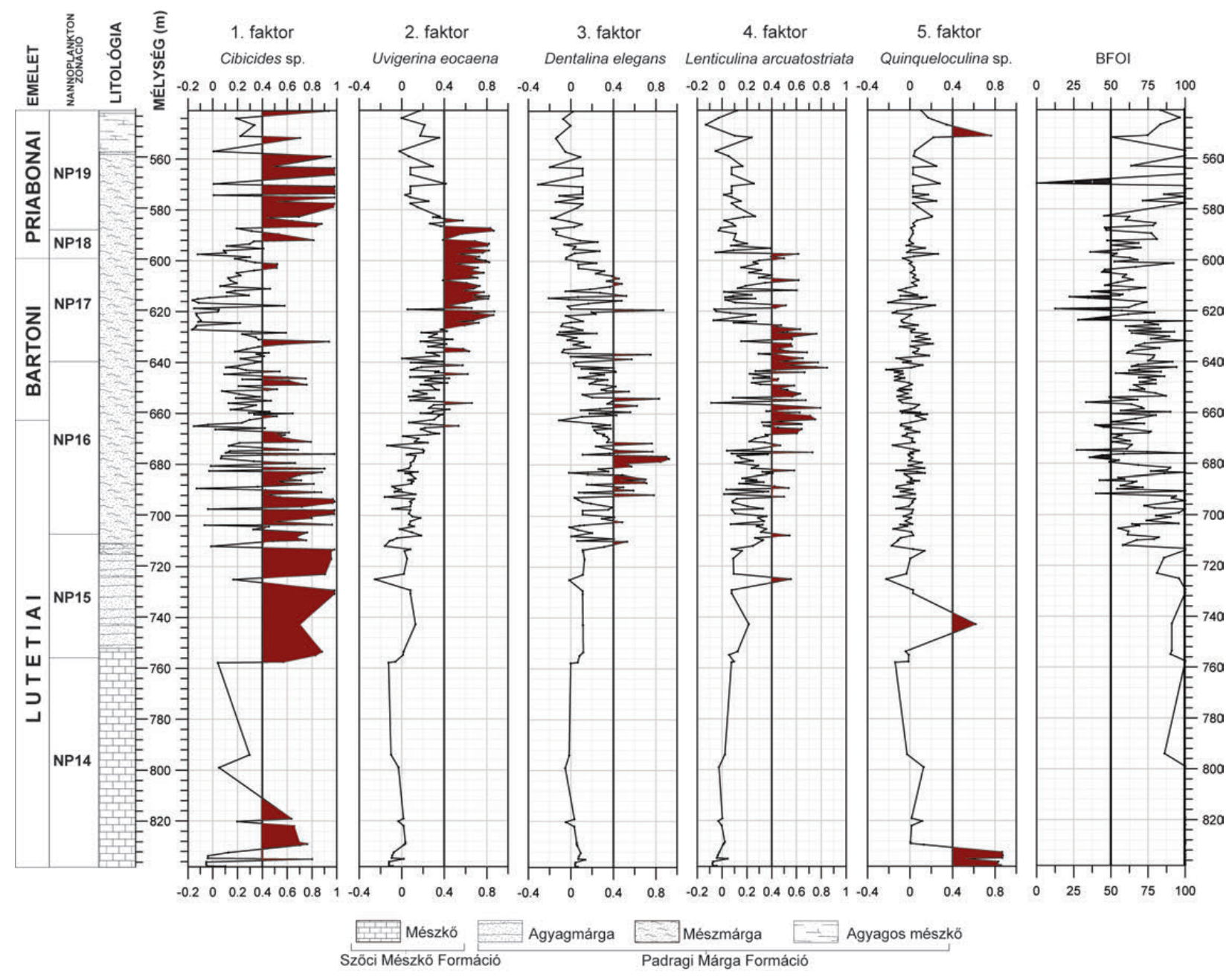

4. ábra A Somlóvásárhely-1 jelű fúrás bentosz foraminifera faunájának főfaktor elemzése és BFOI értékei

Figure 4. Q-mode (Varimax-rotated) factor analysis and benthic foraminiferal oxygen index (BFOI) in the Somlóvásárhely-1 borehole

korábban már publikáltam (OzSVÁRT 1999, 2003, 2007; VETÓ et al. 2007; OzSVÁRT et al. 2016). Mivel a 14 mélyfúrás, illetve két felszíni szelvény részletes ismertetése meghaladja ennek a dolgozatnak a kereteit, ezért itt csak a különbözó részmedencéket legjobban reprezentáló Somlóvásárhely-1 (Sv-1), Csetény-61 (Cst-61), Tarján-14 (Tj-14) és a Cserépváralja-1 (Csv-1) fúrás eredményeit ismertetem részletesen.

\section{Bakonyi részmedence, DNy-bakonyi terület}

\section{Somlóvásárhely-1}

A Sv-1 jelú fúrás 306,8 méteren keresztül harántolt eocén képződményeket (4. ábra). A vizsgált minták a 837,8-541,1 m közötti intervallumból származnak, ami 296,7 m vastag szelvény vizsgálatát engedte. Ennek részletes sztratigráfiai analízise (nannoplankton, plankton foraminifera, magnetosztratigráfia) már korábban megtörtént (BERNHARDT et al. 1988) ezért biztonsággal állítható, hogy az NP14-NP19 nannoplankton zónák között folyamatos üledékképződés zajlott, így a Somlóvásárhely-1 fúrás a legteljesebben reprezentálja a $D N y$-bakonyi terület középsô- és késő-eocén fejlődéstörténetét.
Fauna-összetétel: a szelvény alsó részén (837,8-824 m) fellépő imperforált mészvázú foraminiferák (Miliolina alrend) egyértelmú dominanciája egy erôsen változó sótartalmú lagúna kialakulását feltételezi. Felfelé haladva először az agglutinált vázú foraminiferák aránya nő, majd fokozatosan a perforált mészvázú fajok jutnak uralomra.

Faktoranalizis: a teljes szelvény bentosz foraminiferáinak időbeli változása 5 faktor segítségével írható le (4. ábra), melyek az összvariancia 68,1\%-át magyarázzák. Az 5. faktor (Quinqueloculina sp.) jelentősége csak a szelvény alsó részén van, ahol az 1 . faktorral együtt meghatározóak. Az egész szelvényt vizsgálva kiemelkedik az 1 . faktor (Cibicides sp.) dominanciája. Változás csak a 664-588 m közötti szakaszon figyelhető meg. Ott a 3. faktor (Dentalina elegans) rövid periódusú fellépése mellett először a 4. faktor (Lenticulina arcuatostriata és Cibicidoides dutemplei valamint a Dentalina sp.) majd a 2. faktor (Uvigerina eocaena mint domináns és a Plectina sp., Lenticulina arcuatostriata, mint kapcsolódó fajok) válik meghatározóvá (I. táblázat).

Szervesanyag-fluxus és BFOI: a 837,8-628 m közötti szakaszon a Cibicides sp. és a Lenticulina arcuatostriata, a Cibicidoides dutemplei, valamint a Dentalina sp. (1. faktor, 
I. táblázat. A Somlóvásárhely-1 jelű fúrás főfaktor elemzése során meghatározott domináns és kapcsolódó fajok valamint faktorértékeik

Table I. Factor scores of dominant and associated species from Somlóvásárhely-1 borehole

\begin{tabular}{|c|c|c|c|c|}
\hline Domináns fajok & Faktorérték & Kapcsolódó fajok & Faktorérték & Variancia $(\%)$ \\
\hline 1. faktor & & & & 29,293 \\
\hline Cibicides sp. & 7,63 & & & \\
\hline 2. faktor & & & & 14,056 \\
\hline \multirow[t]{2}{*}{ Uvigerina eocaena } & 4,81 & Lenticulina arcuatostriata & 3,08 & \\
\hline & & Plectina sp. & 3,06 & \\
\hline 3. faktor & & & & 9,162 \\
\hline Dentalina elegans & 5,31 & & & \\
\hline 4. faktor & & & & 11,873 \\
\hline Lenticulina arcuatostriatus & 4,94 & Dentalina sp. & 2,02 & \\
\hline Cibicidoides dutemplei & 4,33 & & & \\
\hline 5. faktor & & & & 3,725 \\
\hline Quinqueloculina sp. & $-7,32$ & Quinqueloculina carinata & $-1,93$ & \\
\hline
\end{tabular}

4. faktor) alapján következtetni lehet a környezet oligotrófmezotróf viszonyaira (KAIHO 1994). A 668-628 m közötti szakaszon a korábbiakhoz képest gyenge lehúlés is feltételezhetô, amire a Lenticulina arcuatostriata (4. faktor) dominanciája alapján következtethetünk (КАIHO 1994). Markáns változás csak 624-588 m közötti szakaszon figyelhetô meg, ahol a BFOI alacsony $(<50)$ értéke jelzi a fenékvizek oxigénben való elszegényedését, ezzel párhuzamosan az inbentosz (Uvigerina eocaena és Lenticulina arcuatostriata) fajok uralomra jutását. Az eutróf környezeti viszonyokat a szelvény felső felében ismét oligotróf környezet váltotta.

\section{ÉK-bakonyi-vértesi kifejlódés$$
\text { Csetény-61 }
$$

A Cst-61 jelû́ fúrás 257 méteren keresztül harántolt eocén képződményeket (5. ábra). A rétegsor az NP16-NP19 nannoplankton zónákba tartozik (BÁLDI-BEKE 1984). Az említett szakaszból összesen 120 mintát vizsgáltam. A bentosz foraminifera közösségról elmondható, hogy a teljes szelvényen keresztuil erôsen változó diverzitást mutat (Ozsvárt 2007 és Vetô et al. 2007). Az alsó és a felsô részen az epibentosz, a középsố szakaszon az inbentosz formák dominanciája jellemzô.

Fauna-összetétel: 520-470 méter között az agglutinált és az imperforált mészvázú foraminiferák hozzávetőleg egyenlő arányú dominanciája jellemzô. Felette az imperforált mészvázú foraminiferák uralkodóvá válnak. 380 métertôl fölfelé az agglutinált foraminiferák arányának növekedése tapasztalható, aminek a maximuma 320-312 méter közötti intervallumra tehető. Ott a fauna közel $60 \%$-át alkotják az agglutinált faunaelemek, amely feltételezi a medencébe áramló terrigén beszállítás fokozódását (OzsváRT 2007).

Faktoranalízis: A bentosz foraminifera közösség értelmezése 5 faktor segítségével szignifikánsan elvégezhető ( 5 . ábra). Az öt faktor az összvariancia 61,38\%-át megmagyarázza. A szelvény alsó felében (480-392 méterig) a 3. faktor
(Lenticulina arcuatostriata), az 1. faktor (Cibicidoides eocaenus), és a 2. faktor (Bulimina truncana) - a kapcsolódó fajok a II. táblázatból kiolvashatók — váltakozva lépi át a szignifikancia küszöböt. A szelvény középső szakaszán (392-318 méterig) a 3. faktor (Lenticulina arcuatostriata), a 4. faktor (Bathysiphon sp.) és az 5. faktor (Lenticulina platyptera) szintén váltakozva domináns. A legfelső részén (318-276 méter között egyértelmúen a 4. faktor (Bathysiphon sp.) a domináns. A domináns és kapcsolódó fajok közös jellemzője, hogy ezek kifejezetten hideg kedvelố genusok (MURRAY 1991), ami alapján feltételezhetô, hogy a teljes üledéksor mélyebb (batiális öv felsô része), illetve húvösebb környezetben rakódott le.

Szervesanyag-fluxus és BFOI: a szelvény alsó felében (520-432 méter között) jól szellőzött, húvös, oligotrófmezotróf környezeti viszonyok feltételezhetôek (kivéve ez alól a 460-472 intervallumot, ahol az inbentosz faunaelemek dominanciája miatt (3. faktor) egy rövidebb eutróf szakasz alakult ki). Fölötte (432-392 méter közötti intervallumban), a Bulimina truncana (2. faktor) számára alakultak ki a legkedvezóbb feltételek. Mivel a kapcsolódó faj (Uvigerina multistriata) is inbentosz faunelem, ezért feltételezhető, hogy az említett tartományban eutróf környezeti viszonyok uralkodtak, hasonlóan a $D N y$-bakonyi fáciesöv különböző szelvényeiben kimutatható, azonos korú (NP17) képződményeihez (OzsvÁRT 2003). Fölötte ismét jól szellőzötté válik a terület, amit jelez az epibentosz faunaelemek ismételt dominanciája. A szelvény felsố szakaszán újra az inbentosz faunaelemek a meghatározók: Bathysiphon sp. (4. faktor), ami feltételezi egy újabb eutróf környezet kialakulását.

A BFOI index értékei alapján 472-446 méter, 432-392 méter és 316-272 méter közötti szakaszon feltételezhetô az aljzat fölött alacsony $(1,5-3 \mathrm{ml} / \mathrm{l})$ oxigén-koncentrációjú fenékvíz kialakulása. Ez szorosan összefügg a fent említett főfaktor-analízis eredményeivel. A köztes intervallumokban oxigénben gazdagabb ( $>3 \mathrm{ml} / \mathrm{l})$ fenékvíz uralhatta a medence aljzatát. 


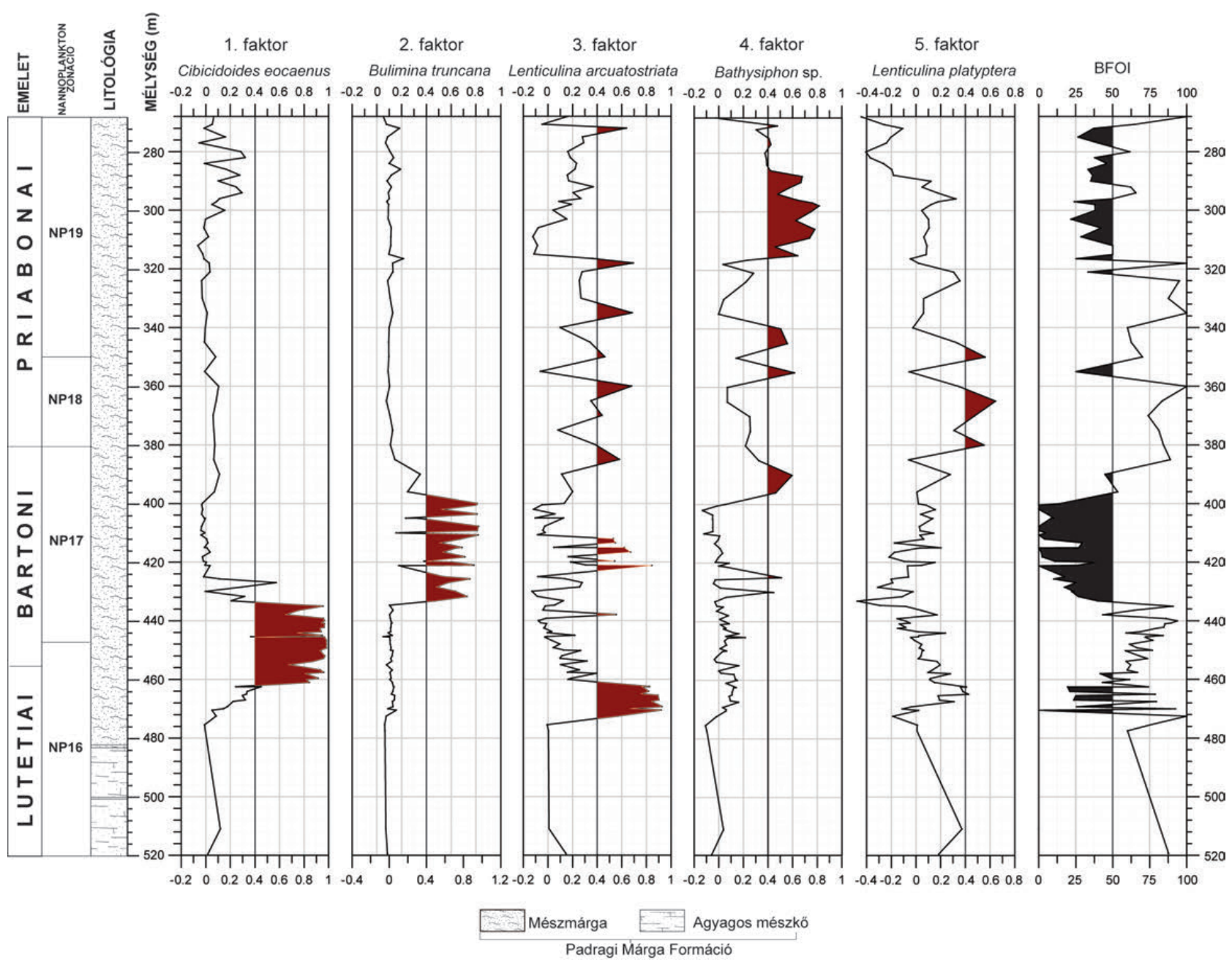

5. ábra A Csetény-61 jelủ fúrás bentosz foraminifera faunájának főfaktor elemzése és BFOI értékei

Figure 5. Q-mode (Varimax-rotated) factor analysis and benthic foraminiferal oxygen index (BFOI) in the Csetény-61 borehole

II. táblázat. A Csetény-61 jelű fúrás főfaktor elemzése során meghatározott domináns és kapcsolódó fajok valamint faktorértékeik

Table II. Factor scores of dominant and associated species from Csetény-61 section

\begin{tabular}{|c|c|c|c|c|}
\hline Domináns fajok & Faktorérték & Kapcsolódó fajok & Faktorérték & Variancia (\%) \\
\hline 1. faktor & & & & 22,582 \\
\hline \multirow[t]{2}{*}{ Cibicidoides eоcaenus } & 9,55 & Cibicidoides perlucidus & 2,16 & \\
\hline & & Cibicidoides dutemplei & 1,83 & \\
\hline 2. faktor & & & & 12,743 \\
\hline Bulimina truncana & 9,71 & Uvigerina multistriata & 2,60 & \\
\hline 3. faktor & & & & 14,196 \\
\hline Lenticulina arcuatostriatus & 9,56 & Lenticulina platyptera & 3,17 & \\
\hline 4. faktor & & & & 7,918 \\
\hline \multirow[t]{2}{*}{ Bathysiphon sp. } & 4,62 & Cibicides sp. & 4,22 & \\
\hline & & Dentalina sp. & 3,69 & \\
\hline 5. faktor & & & & 3,941 \\
\hline \multirow[t]{2}{*}{ Lenticulina platyptera } & 5,32 & Clavulinoides szabói & 3,80 & \\
\hline & & Bolivina elongata & 3,30 & \\
\hline
\end{tabular}




\section{Gerecsei kifejlódés}

\section{Tarján-14}

A Tj-14 jelú fúrás 73,4 méteren keresztül harántolt középsô-eocén (NP16-NP17) rétegsort (6. ábra). A bentosz foraminifera közösség szegényes, általánosan kevés faj és kis egyedszám jellemzi a faunát (OzSVÁRT 2007). Az epibentosz egy szúk intervallumtól eltekintve a teljes szelvényben uralkodik.

Fauna-összetétel: a felső 6 métertől eltekintve a perforált formák dominálnak, az említett szúk intervallumban az imperforált foraminiferák jutnak túlsúlyba.

Faktoranalizis: a bentosz foraminifera közösség értelmezése 4 faktor segítségével szignifikánsan elvégezhető ( 6. ábra). A 4 faktor az összvariancia 73,74\%-át megmagyarázza. A szelvény alsó kétharmadában (433-390 méter között) az 1. faktor (Cibicidoides dutemplei) mellett a 2. faktor (Quinqueloculina carinata, mint domináns faj és Quinqueloculina juleana mint kapcsolódó faj) és a 3. faktor (Bulimina parisensis) is átlépi a szignifikancia küszöböt. Fölötte a 3. faktor (Bulimina parisensis) kizárólagos dominanciája jellemző, majd a 2. faktor (Quinqueloculina carinata, mint domináns faj és Quinqueloculina juleana, mint kapcsolódó faj) és a 4. faktor (Cibicides pygmeus, mint domináns faj és Eponides polygonus, mint kapcsolódó faj) váltakozva meghatározók (III. táblázat).

Szervesanyag-fluxus és BFOI: a szelvényben az inbentosz és epibentosz faunaelemek váltakozva válnak dominánssá. Az alsó kétharmadban (433-390 méter között) az epibentosz Cibicidoides dutemplei (1. faktor) mellett egy szúk intervallumban fellép a Bulimina parisensis (3. faktor) is, ami az inbentosz közösségbe tartozik, ezért feltételezhető a jól szellőzött oligotróf-mezotróf környezet. Fölötte a Bulimina parisensis (3. faktor) dominanciájával rosszul szellőzött, eutróf környezet feltételezhető, majd a szelvény felsô szakaszán ismét az epibentosz túlsúlyba kerülésével oligotróf-mezotróf környezeti viszonyok uralkodtak.

\section{Észak-magyarországi részmedence}

\section{Cserépváralja-1}

A Csv-1 fúrás hozzávetőleg 100 méteren keresztül harántolt legfelsô-eocén és legalsó-oligocén (NP19-NP22) képződményeket (7. ábra). A priabonai Szépvölgyi Mészkő

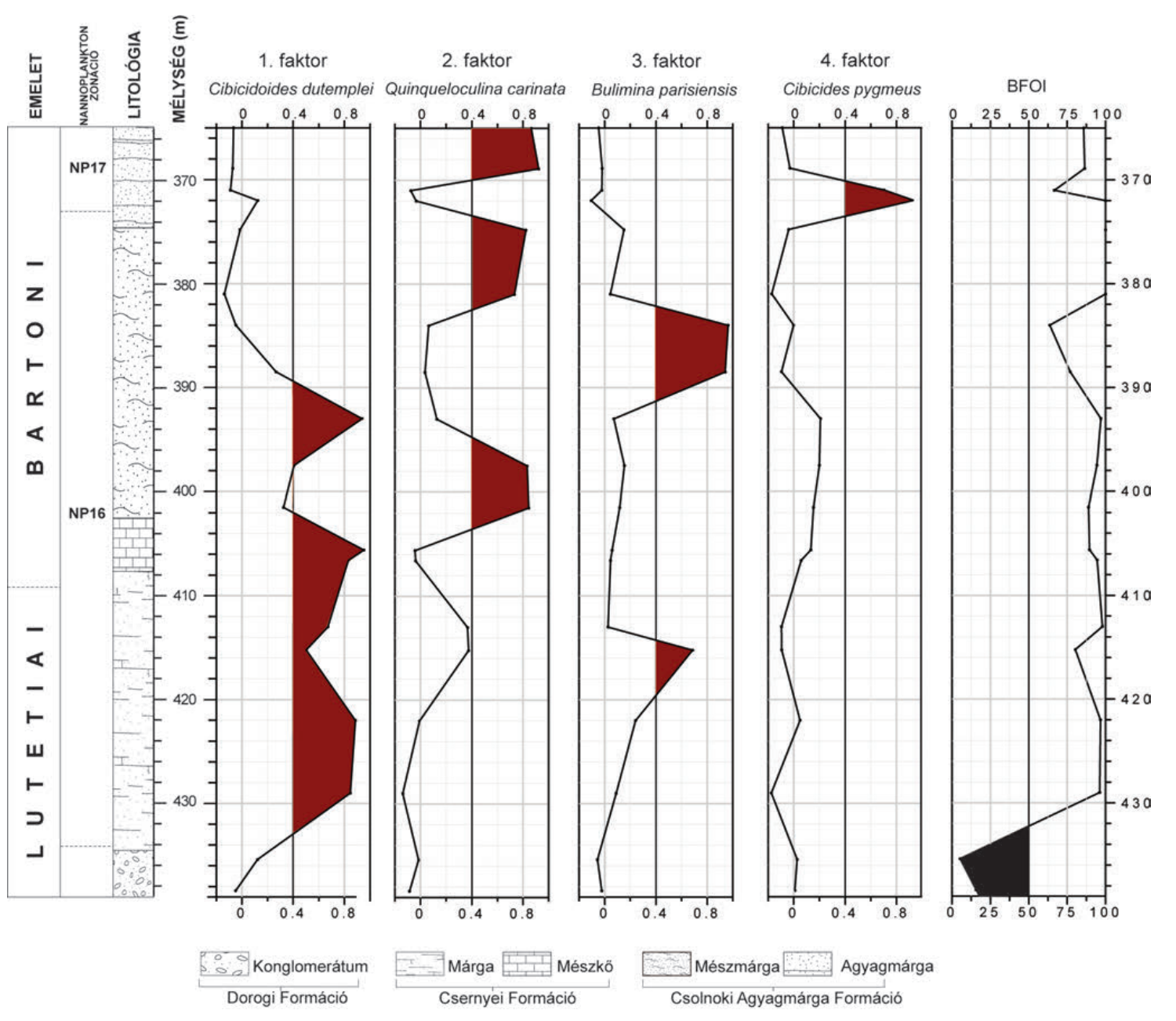

6. ábra. A Tarján-14 jelü fúrás bentosz foraminifera faunájának fófaktor elemzése és BFOI értékei

Figure 6. Q-mode (Varimax-rotated) factor analysis and benthic foraminiferal oxygen index (BFOI) in the Tarján-14 borehole 
III. táblázat. A Tarján-4 számú fúrás főfaktor elemzése során meghatározott domináns és kapcsolódó fajok valamint faktorértékeik

Table III. Factor scores of dominant and associated species from Tarján-14 borehole

\begin{tabular}{|c|c|c|c|c|}
\hline Domináns fajok & Faktorérték & Kapcsolódó fajok & Faktorérték & Variancia (\%) \\
\hline 1. faktor & & & & 21,376 \\
\hline \multirow[t]{2}{*}{ Cibicidoides dutemplei } & 5,76 & Cibicides sp. & 3,49 & \\
\hline & & Cibicidoides eоcaenus & 2,24 & \\
\hline 2. faktor & & & & 12,612 \\
\hline \multirow[t]{4}{*}{ Bulimina truncana } & 4,47 & Uvigerina multistriata & 3,69 & \\
\hline & & Bolivina elongata & 2,84 & \\
\hline & & Cibicides sp. & 2,37 & \\
\hline & & Dentalina subtilis & 2,18 & \\
\hline 3. faktor & & & & 9,06 \\
\hline \multirow[t]{3}{*}{ Pararotalia inermis } & 4,49 & Asterigerina rotula & 3,98 & \\
\hline & & Cibicides sp. & 2,26 & \\
\hline & & Eponides polygonus & 2,18 & \\
\hline 4. faktor & & & & 9,054 \\
\hline \multirow[t]{4}{*}{ Lenticulina arcuatostriata } & 4,77 & Marginulina fragaria & 2,56 & \\
\hline & & Dentalina subtilis & 2,38 & \\
\hline & & Uvigerina eocaena & 2,33 & \\
\hline & & Lenticulina depauperata & 2,18 & \\
\hline 5. faktor & & & & 7,344 \\
\hline Stilostomella sp. & 4,45 & Cibicides sp. & 3,45 & \\
\hline
\end{tabular}

Formáció 426,3 métertól folyamatosan megy át a Budai Márga Formációba. Felfelé haladva 402,0 és 350,0 méterközben a karbonáttartalom jelentősen lecsökken, míg az agyagtartalom folyamatosan növekedni kezd (Tardi Agyag Formáció). 350 és 300 méter között vékonyan rétegzetté, gyakran lemezessé és sötétbarna színúvé válik a márga, ami fölfelé folyamatosan megy át a sötét színú, euxin fáciesú Tardi Agyagba, amiből folyamatosan fejlődik ki később a sekélybatiális Kiscelli Agyag Formáció. Ebben a munkában csak az eocén-oligocén határszakasz $(443,1-364,0)$ vizsgálati eredményeit ismertetem.

Fauna-összetétel: a vizsgált szelvényben dominálnak a perforált foraminiferák, kivéve ez alól a vizsgált szakasz középsô-felső része, ahol túlsúlyba kerülnek az agglutinált (Cyclammina acutidorsata, Bathysiphon saidi, Clavulinoides szaboi stb.) formák (7. ábra).

Faktoranalízis: a bentosz foraminifera közösség értelmezése 5 faktor segítségével szignifikánsan elvégezhetô (7. ábra). Az öt faktor az összvariancia 71,7\%-át megmagyarázza. A szelvény alsó szakaszán (443,1-404,5 méterig) az 1. faktor (Cibicidoides dutemplei) a domináns, a 404,5-382 méter közötti szakaszon a 2. faktor (Uvigerina cocoensis jacksonensis), a 3. faktor (Cyclammina acutidorsata) és a 4. faktor (Bathysiphon saidi) váltakozva dominálnak. 382364 méter közötti szakaszon a 3. faktor és az 5. faktor (Lenticulina inornata) váltakozva dominálnak (IV. táblázat).

Szervesanyag-fluxus és BFOI: a vizsgált szelvény legalsó részén (443,1-409,9 m) a rekonstruált BFOI értékek 40 és 80 közé esnek, ami alapján feltételezhetô, hogy a fenékvíz oldottoxigén-tartalma meghaladta a $3 \mathrm{ml} / \mathrm{l}$ értéket, tehát jól szellőzött, oxigénben gazdag oligotróf környezet feltételezhetô. A 409,9-393 méter közötti szakaszon viszont a BFOI értékek tartósan 50 alá csökkennek $(15<\mathrm{BFOI}<50)$, ami jelzi a fenékvíz oxigénben való elszegényedését, az oldottoxigén-tartalom 1,5-3,0 ml/l közé becsülhető (mezotróf). A vizsgált szelvény felső szakaszán (380-364 méter közötti szakasz) további markáns csökkenés feltételezhető a fenékvíz oldottoxigén-tartalmában $(0,3-1,5 \mathrm{ml} / \mathrm{l})$, így ezen a szakaszon rosszul szellőzött, eutróf környezet kialakulása feltételezhetô.

\section{Diszkusszió}

A megvizsgált 16 szelvény bentosz foraminifera közösségének paleoökológiai elemzése alapján a Magyarországi paleogén medence környezeti viszonyai és azok változásai is jól rekonstruálhatóak. Az elemzés a legfontosabb ökológiai paraméterek időbeli változásait foglalja össze.

\section{A paleogén-medence paleo-oceanográfiai fejlódéstörténete \\ Paleobathymetria}

A Magyarországi paleogén medence képződményei a megszúnő Neotethys-óceán kontinentális peremének sekély litorális övétől (5-30 méter), a szublitorális-mélyszublitorális övön keresztül (30-200 méter), a batiális öv felsố részéig (200-500 méter) rakódhattak le (8. ábra). A mélységbecslés alapja a bentosz közösségek diverzitási indexei- 


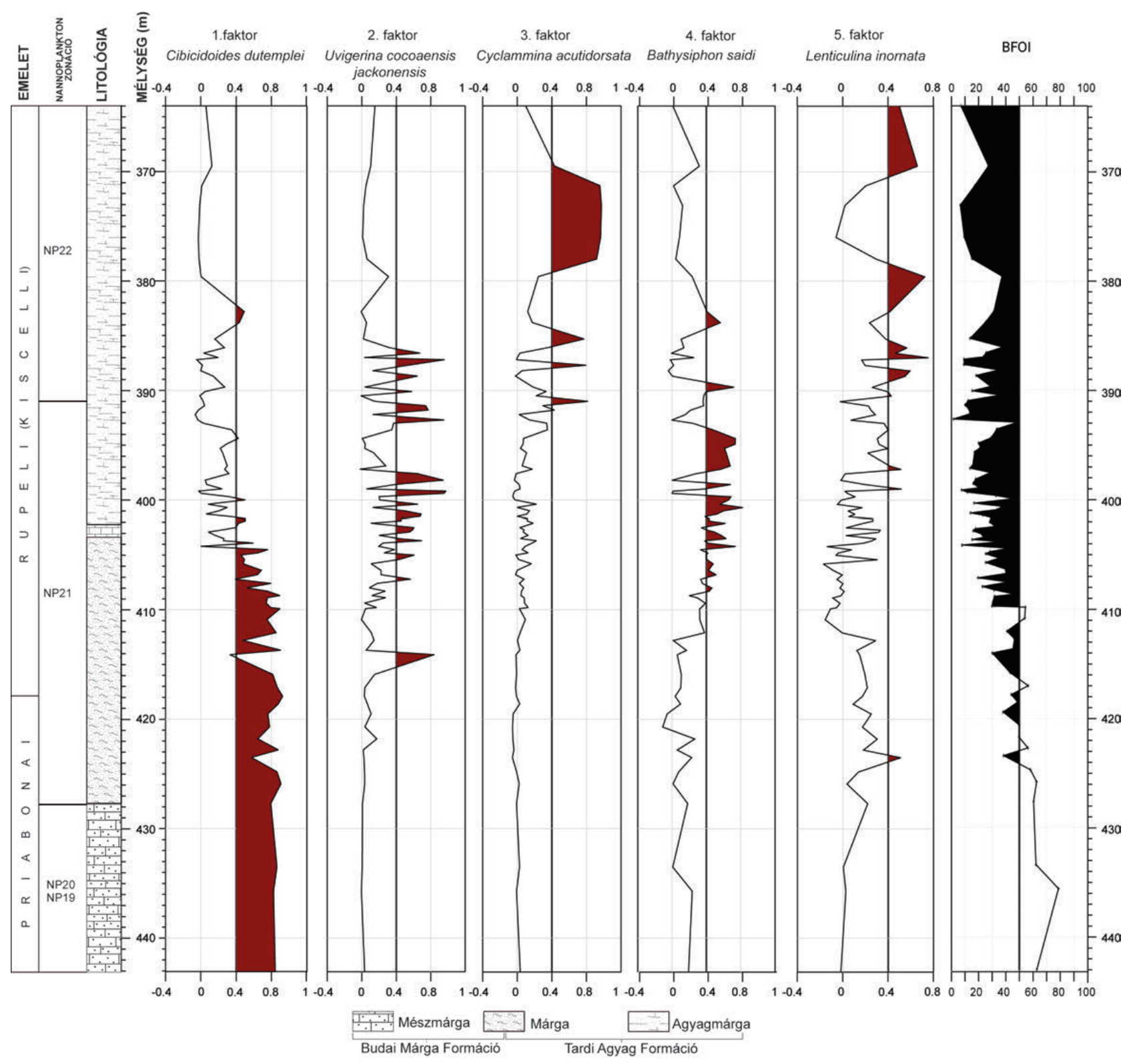

7. ábra. A Cserépváralja-1 jelủ fúrás bentosz foraminifera faunájának föfaktor elemzése és BFOI értékei

Figure 7. Q-mode (Varimax-rotated) factor analysis and benthic foraminiferal oxygen index (BFOI) in the Cerápváralja-1 borehole

IV. táblázat. A Cserépváralja-1 jelủ fúrás főfaktor elemzése során meghatározott domináns és kapcsolódó fajok valamint faktorértékeik

Table IV. Factor scores of dominant and associated species from Cserépváralja-1 borehole

\begin{tabular}{lcccc}
\hline \multicolumn{1}{c}{ Domináns fajok } & Faktorérték & Kapcsolódó fajok & Faktorérték & Variancia (\%) \\
\hline \hline $\begin{array}{l}\text { 1. faktor } \\
\begin{array}{l}\text { Cibicidoides dutemplei } \\
\text { 2. faktor }\end{array}\end{array}$ & 4,41 & & 26,881 \\
$\begin{array}{l}\text { Quinqueloculina carinata } \\
\text { 3. faktor }\end{array}$ & 4,44 & Quinqueloculina juleana & 2,02 & \\
$\begin{array}{l}\text { Bulimina parisensis } \\
\text { 4. faktor }\end{array}$ & 4,44 & & & 12,771 \\
Cibicides pygmeus & 4,03 & Eponides polygonus & 2,74 & 10,018 \\
\hline
\end{tabular}


nek (H(S); $\alpha$ ) változása (OzSvÁRT 2003, 2007), valamint a főfaktor elemzés által meghatározott domináns fajok recens ökológiai igényeinek adatbázisa volt (többek között LUTZE 1980; Murray 1991, 2006; SGARRELla \& MONTCHARMONT ZEI 1993; DE RIJK et al. 1999; SCHERBACHER et al. 2001).

A DNy-bakonyi részmedencében a főfaktor-elemzés eredményei alapján a márgás kifejlődésekben (Padragi Márga) a Dentalina-, Lenticulina-, Uvigerina-, Cibicides-félék szerepeltek a legtöbbször, mint domináns genusok (4-7. ábrák). Az említett közösség tipikusan a belső self és a felső batiális öv (hozzávetőleg 30-500 méter) lakói. A diverzitási indexek $(\mathrm{H}(\mathrm{S})=2-3 ; \alpha=3-9$, OzSVÁRT 2007) alapján becsült mélységadatok (MURRAY 1991) megerôsítik a fent vázolt leülepedési környezeteket (OzSVÁRT 2007). Ugyanakkor jelentôsen különbözik az általam becsült érték HoRvÁth-KolláNYI \& NAgY-Gellai (1988), valamint BÁLDI-BEKE \& BÁLDI (1991) által plankton/bentosz foraminiferák aránya alapján kalkulált eredményeitől (átlagosan 800-1100 méteres vízmélységet becsültek az általam is vizsgált fúrásokban). A jelentős különbség oka véleményem szerint a plankton/bentosz foraminiferák relatív magas (azonban mindig kisebb, mint 60\%) arányában jelentkezik, ami mélyebb régiót jelöl, ugyanakkor a bentosz közösség ennél sekélyebb vízmélységet mutat. Az ellentétes hatást a tápanyagok beáramlásának fokozódása okozhatta, ami felborítja a primer bioprodukciót, és így a plankton szervezetek robbanásszerú elszaporodását, illetve az aljzatra jutó elhalt szerves anyag feldúsulását okozza (a részletes magyarázatot lásd később, a ,Szervesanyag-fluxus, a fenékvíz oxigénellátottsága c. fejezetben).

Az ÉK-bakonyi-vértesi területen a Cibicidoides-, Bulimina-, Quinqueloculina-félék szerepeltek a legtöbbször, mint domináns genusok (5-7. ábrák). Az idősebb képződményekben (Csernyei Formáció, Szốci Mészkő Formáció alsó része és Csolnoki Agyagmárga alsó része) a Quinqueloculina és más Miliolina genusok elsôsorban sekély (0-30 méter) környezetet jeleznek. A fiatalabb képződményekben (Csolnoki Agyagmárga felsô része és Padragi Márga) a Cibicidoides- és a Bulimina-félék dominanciája egyértelmúen mélyülést jeleznek a bartoni (NP17 zóna) végére. A terület üledékei feltételezhetően 300-500 méter mélységben képződhettek (8. ábra). Hasonló mélységviszonyok becsülhetők a diverzitási indexekből is $(\mathrm{H}(\mathrm{S})=0,5-3 ; \alpha=$ 2-9; OzSVÁRT 2007).

A Gerecsei terület kevésbé egységesíthető, változatos képet mutat, elsôsorban a self litorális, szublitorális övének jellegzetes faunaelemeivel: Nonion-, Pararotalia-, Miliolina-félék (6. ábra). A diverzitási indexek helyenként extrém alacsony értékei $(\mathrm{H}(\mathrm{S})=0,5-1,2 ; \alpha=1-3$, OzsvárT 2007) megerősítik a sekélytengeri (0-50 méter) környezet kialakulását és tartós jelenlétét. A Gerecsei terület északi részén azonban a Padragi Márga (korábban Piszkei Márga) megjelenésével a DNy-bakonyi területhez, ill. az Észak-magyarországi részmedencéhez hasonló feltételek alakulhattak ki, azaz hozzávetôleg 300-500 méteres vízmélység feltételezhető (8. ábra).

Az Észak-magyarországi részmedencében a késő- eocéntől dominálnak a tipikusan self és felsô batiális öv (hozzávetôleg 300-500 méter) genusai (Cibicidoides spp., Lenticulina spp.) valamint a relatív magas diverzitási indexek $(\mathrm{H}(\mathrm{S})=2-3,5 ; \alpha=3-9$ (OZSVÁRT et al. 2016).

\section{Hômérséklet, sótartalom}

A bentosz foraminifera közösségek diverzitását és a fauna-összetételt jelentôsen befolyásolja a tengervíz hőmérséklete és sótartalma is. Hatványozottan igaz ez a self sekélyebb, illetve mélyebb zónáira, mivel ezekben a régiókban az említett fizikokémiai paraméterek változása jóval rövidebb idő alatt mehet végbe, mint a batiális, vagy az abisszikus övben. Amíg a sekély tengerrészekben a hőmérséklet és/vagy sótartalom változása akár szezonálisan is jelentős lehet, addig a medencék aljzatát kitöltő fenékvizekre gyakorolt felszíni vizek hőmérséklet-ingadozása, illetve a hulló csapadék mennyiségének hatása gyakorlatilag jelentéktelen.

A DNy-bakonyi területen a fófaktor elemzés eredményei alapján az NP16 nannoplankton zónáig egyértelmúen meleg (18-23 C, BETzLER et al. 1997 alapján), változó sótartalmú környezeti viszonyok kialakulását feltételezhetjük a Miliolina- (főleg Quinqueloculina-félék), illetve a Cibicidesfélék dominanciája és az általánosan alacsony $(\mathrm{H}(\mathrm{S})=0,5-$ 1,$5 ; \alpha=2-4$ ) diverzitási indexek értékei alapján (OzSvÁRT 2007). Változás a lutetiai végétől (NP16 zóna) ismerhető fel először, amikor hidegebb vizeket (10-15 C, MURRAY 1991 alapján) kedvelô genusok megjelenésével (Lenticulina, Cibicidoides, Eponides stb.) lehúlés feltételezhetô (9. ábra). Ebben a fáciesövben a mérsékelt-hideg $\left(15-18^{\circ} \mathrm{C}\right)$ kedvelő fajok dominanciája a priabonai elejéig (NP18 zóna felső szakaszáig) tart. Kizárólag a Somlóvásárhely Sv-1 számú fúrásban maradt meg biosztratigráfiai eszközökkel igazolhatóan NP19 nannoplankton zónába tartozó üledék, ahol a Cibicides sp. dominanciája mérsékelt, meleg-mérsékelt hőmérsékletet jelöl.

$\mathrm{Az}$ ÉK-bakonyi-vértesi területen az NP16 nannoplankton zónába tartozó üledékekben a meleg, változó sótartalmú környezeti viszonyok uralkodtak elsősorban a Miliolinafélék dominanciája alapján. A húvösebb vizeket kedvelő fajok ebben a fáciesövben a bartoni elején (NP16 zóna felső szakaszán) jelennek meg, uralkodóvá a bartoni idősebb és a priabonai fiatalabb (NP17-NP18 zónák) részén válnak.

A Gerecsei területen az NP16-NP17 nannoplankton zónába tartozó üledékek meleg, gyakran változó sótartalmú környezetben rakódtak le, amire a Miliolina-félék dominanciája és az egyenletesen alacsony diverzitási indexek $(\mathrm{H}(\mathrm{S})=0,5-1,5 ; \alpha=2-3)$ alapján következtethetünk (OzSVÁrt 1999, 2003, 2007).

Az Észak-magyarországi részmedencében a középsőpriabonaitól (NP19 zónától kezdődően) mérsékelt-hideg kedvelő fajok dominanciája jellemző majd a rupelitól (NP22 zóna) már egyértelmúen hidegebb vizeket kedvelő genusok népesítették be a medencealjzatot.

Hasonló, tendenciaszerú változást észlelt KoLLÁNYI et al. (1997). A lutetiai végétôl (NP16 zónában) megindult és a 

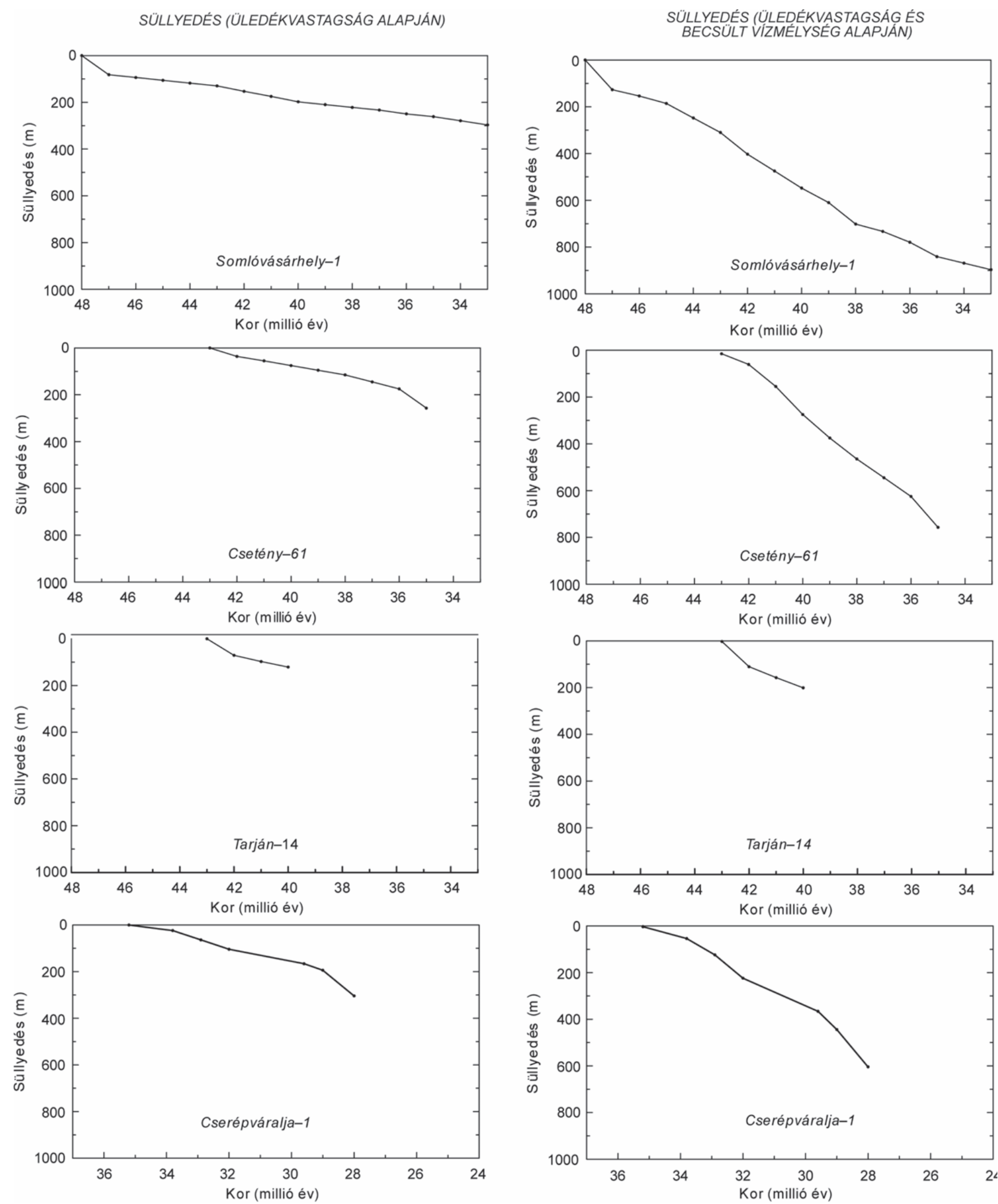

8. ábra. A Magyarországi paleogén medence négy fúrásának süllyedésgörbéi, figyelembe véve a képződmények vastagságait illetve a becsült vízmélységeket Figure 8. Subsidence curves for four exploration wells from the Hungarian Palaeogene Basin with and without palaeowater depth estimates

bartoniban (NP17 zóna) kulmináló lehúlést mutattak ki a Sv-1, illetve Csatka-2 jelú fúrások bentosz és plankton foraminiferáinak oxigén- és szénizotóp vizsgálataiban. Ez egybeesik a fófaktor-elemzések által meghatározott hideg- kedvelő fajok megjelenésével és dominánssá válásával. Az általuk feltételezett $3-8{ }^{\circ} \mathrm{C}$-os lehúlés $\left(\delta^{18} \mathrm{O}\right.$ lokális maximuma) azonban nem csak a két bakonyi szelvényben mutatható ki. OBERHÄNSLI et al. (1991) négy azonos korú 
dél-atlantikumi DSDP fúrásban hasonló $\delta^{18} \mathrm{O}$ maximumot talált. WADE \& KROON (2002) az Észak-Atlantikum nyugati részén mélyített ODP fúrásban az NP17 nannoplankton zónát reprezentáló szelvényt vizsgáltak és kimutatták a bakonyival egyidős $\delta^{18} \mathrm{O}$ maximumot. Feltételezésük alapján a $\delta^{18} \mathrm{O}$ értékek maximuma már egy kialakulóban lévő antarktiszi jégtakaró létezését valószínúsítik, melynek közvetett globális klimatológiai és oceanológiai hatásai feltételezhetôen a Tethys kisebb részmedencéiben is érzékelhetőek voltak. Megerôsíti a kezdődő lehúlés folyamatát az NP17 nannoplankton zóna végén jelentkező jelentős kihalási esemény is, amely elsősorban a trópusi plankton szervezeteket (Morozovellidae, Acarininidae) érintette (BOERSMA et al. 1987).

\section{Szervesanyag-fluxus, a fenékvíz oxigénellátottsága}

Az utóbbi évtizedek recens és fosszilis bentosz foraminifera közösségeinek elemzéseiben kiemelkedő szerepet kapott a medencébe áramló szerves anyag mennyiségének és a fenékvíz oldottoxigén-tartalmának a vizsgálata (többek között JORISSEN 1987, ALTENBACH \& SARNTHEIN 1989, KAIHO 1991, 1994; SCHERBACHER 2001; SCHMIEDL et al. 2002).

A DNy-bakonyi terület aljzatáról általánosan elmondható, hogy az üledékképződés kezdetétől jól szellőzött, alacsony szervesanyag-fluxus valamint oligotróf-mezotróf viszonyok jellemezték. Azonban a lutetiai végétől (NP16 zóna) az Sv-1 és Halimba-1 fúrásokban (OzSVÁRT 2003) egy szúk intervallumban kimutatható egy kisebb eutrofizációs folyamat, melyet később oligotróf-mezotróf viszonyok váltottak (9. ábra). A bartonitól (NP17 felsố és az NP18 nannoplankton zóna alsó részén) a korábbival szemben egy markáns eutrofizációs folyamat feltételezhető (Sv-1, Devecser-4 és Padrag-5 fúrások [OzSVÁRT 2003]), ami összefüggésben lehet a fenékre áramló növekvő szervesanyag- és/vagy csökkenő oxigénmennyiséggel. Ezen kívül egy rövidebb periódusú eutróf környezet kialakulását is feltételezhetjük $(\mathrm{Sv}-1)$ a priabonai középső részén (NP19 zóna) (9. ábra).

Az ÉK-bakonyi-vértesi fáciesöv aljzata szintén jól szellőzött volt az üledékképződés megindulást követően, alacsony szervesanyag-fluxus jellemezte, elsősorban oli-

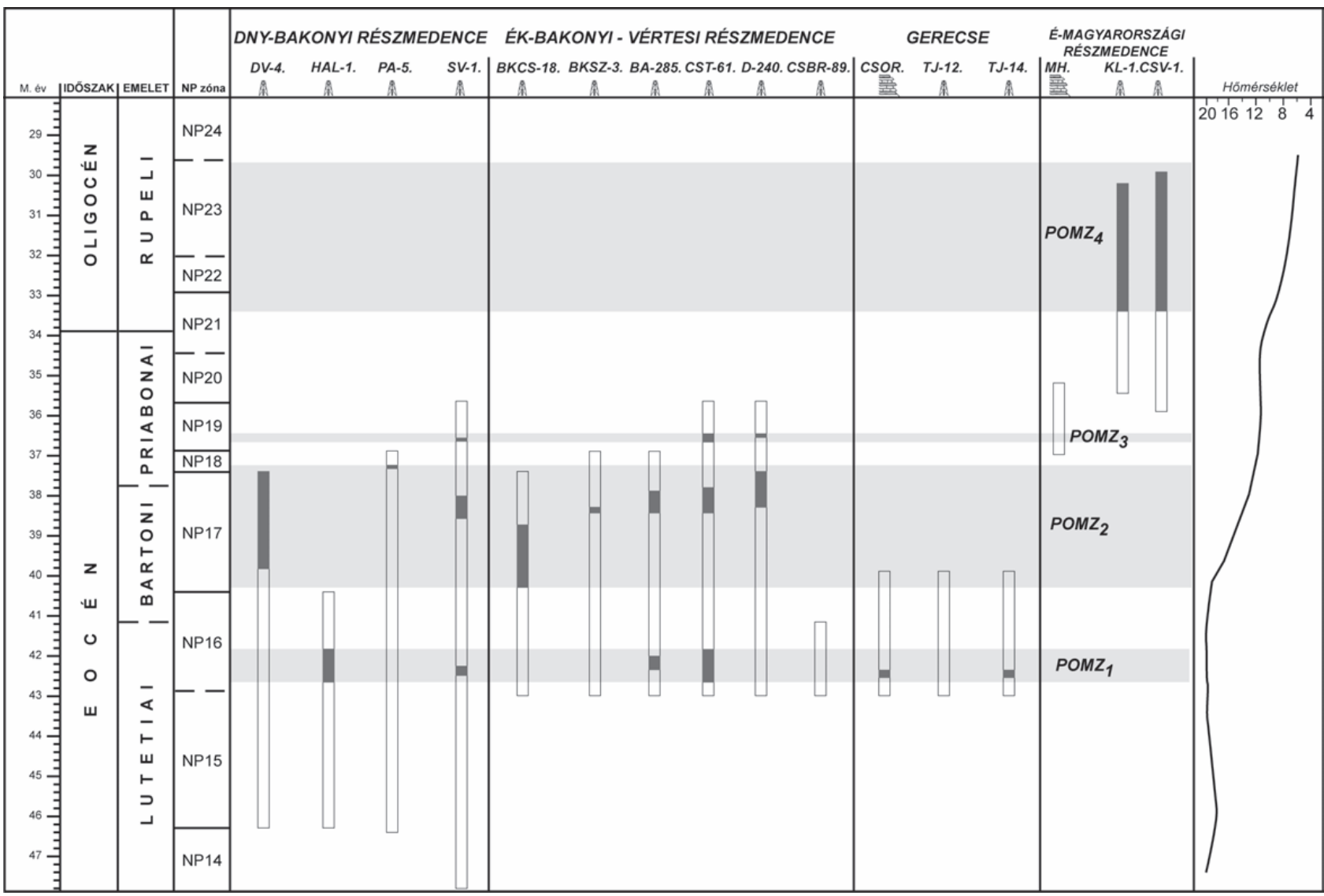

9. ábra. A Magyarországi paleogén medencében bentosz foraminifera közösségek változásai alapján kimutatható eutrofizációs események (POMZ1-4). DV-4 = Devecser-4, HAL-1 = Halimba-1, PA-5 = Padrag-5, SV-1 = Somlóvásárhely-1, BKCS-18 = Bakonycsernye-18, BKSZ-3 = Bakonyszentkirály-3, BA-285 = Balinka-285, CST-61 = Csetény-61, D-240 = Dudar-240, CSBR-89 = Csákberény-89, CSOR. = Csordakúti külfejtés, TJ-12 = Tarján-12, TJ-14 = Tarján-14, MH. = Mátyás-hegy, keleti kőfejtő, KL-1 = Kiscell-1, CSV-1 = Cserépváralja-1

Figure 9. Eutrophic events (POMZ) in the Hungarian Palaeogene Basin. DV-4 = Devecser-4, HAL-1 = Halimba-1,PA-5=Padrag-5, SV-1=Somlóvásárhely-1, BKCS$18=$ Bakonycsernye-18, BKSZ-3 = Bakonyszentkirály-3, BA-285 = Balinka-285, CST-61 =Csetény $-61, D-240=$ Dudar $-240, C S B R-89=$ Csákberény-89, CSOR. $=$ Csordakút Quarry, TJ-12 = Tarján-12, TJ-14 = Tarján-14, MH. = Mátyás-hegy quarry, KL-1 = Kiscell-1, CSV-1 = Cserépváralja-1 
gotróf-mezotróf környezeti feltételek uralkodtak. Változás csak az NP16 nannoplankton zóna középsô részén kezdődik, amikor két fúrásban (Cst-61, Balinka-285; [OzSvÁRT 2003]) egy rövidebb eutrofizációs folyamat ismerhetô fel. Az, hogy ez a folyamat csak két fúrásban jelentkezik, feltételezhetôen a változatos aljzattopográfia következménye volt. Azonban a bartoni (NP17 felső és az NP18 nannoplankton zóna alsó) felső és a priabonai alsó részén már az összes vizsgált fúrásban kimutatható a $D N y$-bakonyi fáciesöv különböző szelvényeihez hasonlóan egy markáns eutrofizációs folyamat. Azt követően ismét jól szellőzötté vált a terület, azonban két szelvényben (Cst-61 és D-240) a priabonaiban (NP19 zóna) belül is feltételezhető egy rövid időtartamú eutróf és alacsony oldottoxigén-koncentrációjú környezet kialakulása (9. ábra).

A Gerecsei fáciesövben a bentosz foraminifera közösségek jól szellózött, oligotróf-mezotróf viszonyokat mutatnak, azonban az NP16 nannoplankton zónán belül a bakonyi területek azonos korú képződményeihez hasonlóan itt is felismerhető egy rövid periódusú, eutróf környezet kialakulása (9. ábra).

Az Észak-magyarországi részmedencében az NP19NP21-es nannoplankton zóna középsô részéig jól szellőzött, oligotróf viszonyok uralkodtak ( $>3 \mathrm{ml} / 1 \mathrm{O}_{2}$ ), ezt követően folyamatos eutrofizációs folyamat ismerhető fel, fokozódott a medencébe áramló szerves anyag mennyisége és erôteljesen csökkent az oldottoxigén-tartalom (1,5-3 ml/1 $\left.\mathrm{O}_{2}\right)$. Az NP22 nannoplankton zóna közepéig kifejezetten eutróf viszonyok uralkodtak $\left(0,3-1,5 \mathrm{ml} / \mathrm{l} \mathrm{O}_{2}\right)$. Ezt követôen az NP23 nannoplankton zóna felső szakaszáig szélsőségesen oxigénszegény, anoxikus környezet alakult ki a medence aljzatán (BÁLDI 1980).

Különösen jelentős szerepe van a medencébe áramló szerves anyag mennyiségének sekély, szigetekkel tagolt selftengerekben, illetve zárt, vagy közel zárt medencékben (pl. fjordokban), ahol a foraminiferák mélységbeli elterjedését nagyban befolyásolják a külső környezeti hatások (édesvíz-beáramlás, szervesanyag-fluxus, hőmérséklet stb.) (Alve 1990, Sen Gupta \& Machian-Castillo 1993). Gyakran előfordul, hogy tipikusan mélyebb (pl. batiális) környezetet jelző foraminifera közösség (plankton és bentosz együtt) jelenik meg sekélyebb (pl. szublitorális, mélyszublitorális) környezetben, melyet elsôsorban a medencébe áramló tápanyag, illetve a fenékvíz alacsony oldottoxigén-koncentrációja szabályoz. Az ellentétes hatást a tápanyagok beáramlásának fokozódása okozhatja, ami felborítja a primer bioprodukciót, és így a plankton szervezetek robbanásszerú elszaporodását, illetve az aljzatra jutó elhalt szerves anyag feldúsulását okozza. Ez szoros összefüggésben van a fenékvíz oldottoxigéntartalmával, ugyanis a felhalmozódó szerves anyag bomlása nagy mennyiségú oxigént von el a környezettől, így alakulhatnak ki az aljzaton mezotróf, eutróf, illetve szélsőséges — vertikális és horizontális áramlatoktól mentes - esetekben anoxikus környezeti viszonyok. Ezt az ún. teleszkóphatást mutatta ki az alpi molassz öv alsóoligocén képződményeiből SCHERBACHER et al. (2001).
Véleményem szerint a Magyarországi paleogén medencében HorvÁTH-KolláNYI \& NAGY-GELlAI (1988) valamint BÁLDI-BEKE \& BÁLDI (1991) által plankton/bentosz foraminiferák aránya alapján jelzett, helyenként extrém mértékú ,süllyedést” sokkal inkább a fent vázolt teleszkóphatás okozhatta. Feltevésem szerint a nagyobb mennyiségú tápanyag-beáramlás a plankton szervezetek robbanásszerú elszaporodását eredményezte, ami a plankton/bentosz arány növekedését okozta. Az említett szerzók által becsült süllyedés ütemének megindulása szinte méterre pontosan egybeesik az általam az NP17 nannoplankton zónában kimutatott jelentős eutrofizációs folyamat megindulásával, ami így nem egy hirtelen kimélyülésnek, hanem jelentős oceanológiai eseménynek is tekinthető.

Megerősíti a rövid periódusú eutrofizásciós időszakok kialakulását BÁLDI-BEKE és BÁLDI (1991) által néhány bakonyi fúrásban (Cst-61, Bakonycsernye-18) már korábban leírt, vékony (általában 10-20 méter), lemezes, pelites agyag megjelenése a középső-bartoniban (NP17 zóna). A litológiai bélyegek által feltételezett, BÁLDI-BEKE \& BÁLDI (1991) által lokális anoxikus események tekintett epizód véleményem szerint a medence más részein is kimutatható a bentosz foraminiferák részletes paleoökológiai vizsgálatával.

További bizonyítékul szolgálhat a paleo-oceanográfiai magyarázat mellett a bartoniban (NP17 zóna) kialakult regresszív üledéksor is. Erre litológiai bizonyítékot elsôsorban az ÉK-dunántúli területen találunk, ahol mintegy 200 méteres vastagságban a medencék feltöltődését jelző mészkő-, márga- és homok-, homokkőrétegek váltakozásából felépülő regressziós rétegsor húzódik, annak zárótagjaként pedig széntelepes összlet is kifejlődött (Dorogi-medence keleti része, BERNHARDT 1984). A medence irányába mozgó partvonal mögötti kiterjedt erózió pedig megnövelhette a medencébe áramló tápanyag relatív mennyiségét, ami a primer bioprodukció megváltozását okozta. A bakonyi területen a regresszív hatást elsősorban a bentosz foraminifera közösségen belüli markáns diverzitás csökkenés (OzSVÁRT 2007 munkájában a 7. ábra) alapján feltételezhetjük, ami szoros összefüggésben van a vízmélységgel (MurRAY 1991). Mindezek mellett a bartoni alsó szakaszán — az eocén egyik legjelentősebb — mintegy 100-130 méteres globális tengerszintcsökkenést mutattak ki (HARDENBOL et al. 1998), ami feltételezheti ennek a globális vízszintesésnek a területen kifejtett hatását is.

\section{A paleogén medence paleo-oceanográfiájának fejlódéstörténeti modellje}

A fenti paleoökológiai paraméterek változása alapján a következő fejlődéssor állítható fel. A középső-eocén kezdetén (NP14-NP15) jól szellőzött, magas oldottoxigén-koncentrációjú víz töltötte ki a $D N y$-bakonyi medencét, és a süllyedéssel lépést tartó, kisméretű karbonátplatform tudott kiépülni a területen. A késő-lutetiaiban (NP16) megindult az üledékképződés az ÉK-bakonyi-vértesi és Gerecsei rész- 
medencékben is. A kezdeti jól szellőzött medencében a lutetiain (NP16 zóna) belül egy gyenge eutrofizációs folyamat jelentkezik, ami a medence aljzatának alacsony oldottoxigén-tartalmára utal (10. ábra). Az elsố ilyen oxigénben szegényebb esemény a Paleogén Oxigén Minimum Zóna $\left(\mathrm{POMZ}_{1}\right)$ (9. ábra). Az egyenlótlen topográfia következtében a magasabb térszínen (a self litorális övében) nem alakulhattak ki eutróf környezeti viszonyok. Ezt követően jól szellőzötté vált a terület és ismét oligotróf környezet alakult ki. A középsô-eocén végén jelentős változás következik be. A bentosz közösség együttes regressziót és jelentôs, az összes relatív magasabban elhelyezkedố területre is kiterjedő, eutrofizációs eseményt jelez $\left(\mathrm{POMZ}_{2}, 9\right.$. és 10.
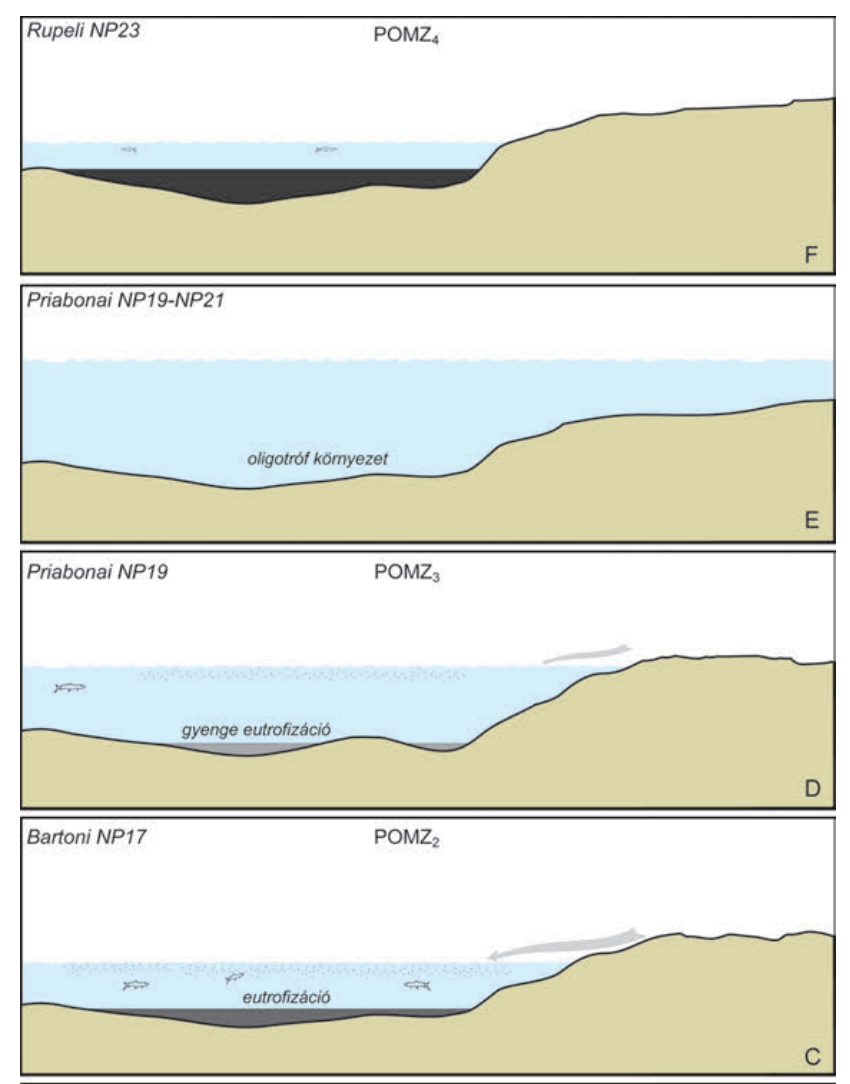

Lutetiai - Bartoni NP16-NP17
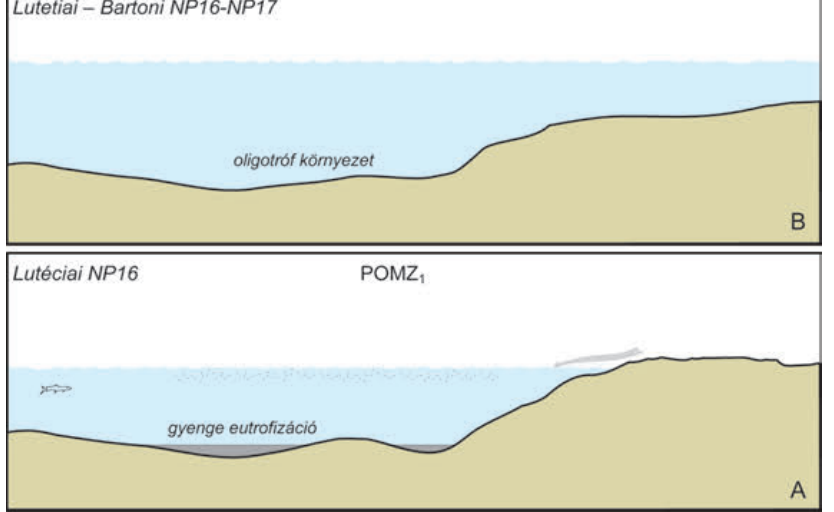

10. ábra A Magyarországi paleogén medence paleo-oceanográfiai fejlődéstörténete a lutetiaitól (NP16) a rupéli (NP23) végéig

Figure 10. Palaeo-ocenographic evolution of the Hungarian Palaeogene Basin during the late Palaeogene (Lutetian to Rupelian) ábra), amit az oxigénben dús, mélyebb áramlatok képtelenek voltak áthatolni, így vált rosszul szellőzötté, alacsony oldottoxigén-tartalmúvá a medence (10. ábra). A késôeocénben bekövetkezô relatív tengeszint-emelkedés ismét oligotróf környezetet eredményezett, ami feltételezhetóen a beáramló hidegebb fenékvizek ventillációs mechanizmusának köszönhető. A priabonaiban (NP19 zóna) a POMZ ${ }_{1}^{-}$ hez hasonló gyenge eutrofizációs esemény tételezhetô fel $\left(\mathrm{POMZ}_{3}\right)$. Végül az NP21-NP23 zónán belül alakult ki a legmarkánsabb eutrofizációs folyamat $\left(\mathrm{POMZ}_{4}\right)$, amely a vizsgált időszak végére euxin környezet (10. ábra) kialakulást eredményezte (BÁLDI 1980).

\section{Következtetések}

A megvizsgált középső- és felsô-eocén rétegsorok bentosz foraminifera közösségeinek időbeli változása alapján a következő megállapítások tehetốk a Magyarországi paleogén medence eocén paleo-oceanológiai fejlődéstörténetére vonatkozólag.

A bentosz foraminifera közösség szignifikáns fajai a self különböző mélységöveinek és a batiális öv felső részének tipikus formái.

A középsô-, és késô-eocén folyamán képződött üledékek a bentosz foraminiferák paleoökológiai elemzése alapján a kontinentális self sekély litorális (Szóci Mészkó, Csernyei Mészkố, Csolnoki Agyagmárga és Szépvölgyi Mészkô) övétôl (5-30 méter), a szublitorális-mélyszublitorális övön (Szốci Mészkố, Csolnoki Agyagmárga és Szépvölgyi Mészkó) keresztül (30-200 méter), a batiális öv (Padragi Márga, Budai Márga és Tardi Agyag) felső részéig (200-500 méter) rakódhattak le.

A középső-eocén elején a sekélyebb és a relatív mélyebb övekben is meleg $\left(18-23{ }^{\circ} \mathrm{C}\right)$ tengervíz a lutetiai végén meginduló fokozatos lehúlést szenved $\left(10-15{ }^{\circ} \mathrm{C}\right)$. A $D N y$ bakonyi és az ÉK-bakonyi-vértesi terület között az idóben eltolódó lehúlés feltételezhetően topográfiai különbségeknek köszönhetô. A lehúlés folyamata összefüggésben lehetett a már kialakulóban lévő antarktiszi jégtakaró közvetett hatásaival.

A plankton/bentosz foraminiferák aránya alapján detektált, helyenként extrém mértékú látszólagos süllyedés magyarázható a sekélyebb, szigetekkel tagolt selftengerekben, illetve zárt vagy közel zárt medencékben gyakori teleszkóphatással is. Ez nagyobb mennyiségú tápanyag beáramlásnál a plankton szervezetek robbanásszerú elszaporodását eredményezi, ami a plankton/bentosz arány növekedését okozza. A korábban feltételezett süllyedés ütemének növekedése egybeesik az NP17 nannoplankton zónában kimutatott jelentős eutrofizációs folyamat megindulásával, ami így nem hirtelen kimélyülésként, hanem oceanológiai eseményként is értelmezhetô.

A középsô-eocén alsó részén a sekélytengeri epibentosz fauna dominanciája oligotróf, mezotróf környezetet jelez. A lutetiai végén (NP16) a litorális övben továbbra is oligotróf viszonyok uralkodnak, ugyanakkor a 
viszonylag mélyebb zónában az inbentosz faunaelemek uralomra jutása eutróf, alacsony oxigénkoncentrációjú környezet jelez. Fölötte ismét oligotróffá válnak a mélyebb medencerészek is. A bartoni végén (NP17), illetve bizonyos területeken a priabonai elején (NP18) ismét az inbentosz fauna dominanciája jellemzô, ami a környezet eutróf állapotára utal. A medencék újabb átszellőzött periódusa után a priabonai középsô részén (NP19) is kimutatható egy gyenge mezotróf-eutróf állapot, majd az NP21-NP23 szakaszon markáns eutrofizáció zajlott a medencében. A fenti folyamatok alapján két gyengébb $\left(\mathrm{POMZ}_{1}\right.$ és $\left.\mathrm{POMZ}_{3}\right)$ és két markáns $\left(\mathrm{POMZ}_{2}\right.$ és $\left.\mathrm{POMZ}_{4}\right)$ eutrofizációs esemény detektálható a bentosz foraminifera fauna összetételének változása alapján.

\section{Köszönetnyilvánítás}

Megkülönböztetett hálával tartozom Dr. KoLLÁNYI Katalinnak, valamint az egykori Magyar Állami Földtani Intézetnek, hogy a vizsgálataimhoz rendelkezésemre bocsátották a mélyfúrások bentosz foraminifera anyagát. A Somlóvásárhely-1 jelú fúrás esetében a fajok határozásánál figyelembe vettem Dr. KolLÁNYI Katalin eddig nem publikált és a rendelkezésemre bocsátott eredményeit is. A kutatást az OTKA K112708 számú projektje támogatta. Ezúton szeretném megköszönni Dr. KERCSMÁR Zsolt részletes és minden tekintetben épító kritikáját. Köszönettel tartozom továbbá Dr. SzTANó Orsolyának hasznos kritikai észrevételeiért, valamint a nevét nem vállaló lektor hozzászólásaiért. A kézirat alapos technikai javításait Dr. DuLAI Alfrédnak köszönöm.

\section{Irodalom - References}

Altenbach, A. V. \& SARnthein, M. 1989: Productivity record in benthic foraminifera. — In: Berger, W. H., SMEtACEK, V. S. \& Wefer, G. (eds): Productivity of the ocean: Present and past. Life Science Research, New York, 255-269.

ALVE, E. 1990: Variation in estuarine foraminiferal biofacies with diminishing oxygen condition in Drammensfjord, SE Norway. — In: Hemleben, Ch., Kaminski, M. A., Kuhnt, W. \& Scott, D. B. (eds): Paleoecology, biostratigraphy, paleoceanography and taxonomy of agglutinated foraminifera. NATO ASI, series C, 327. 661-694. https://doi.org/10.1007/978-94-011-3350-0_23

BÁLDI T. 1980: A korai Paratethys története. (The early history of the Paratethys). — Földtani Közlöny 110, 456-472.

BÁLDI T. 1983: Magyarországi oligocén és alsómiocén formációk. (The Oligocene and Lower Miocene formations of Hungary). — Akadémiai Kiadó, Budapest, 1-293.

BÁLDI-BEKE M. 1984: A dunántúli képződmények nannoplanktonja. (The nannoplankton of the Transdanubian Paleogene formations). - Geologica Hungarica, series Palaeontologica 43, 1-307.

BÁldi-BeKe, M. \& BÁLdI, T. 1991: Paleobathymetry and Paleogeography of the Bakony Eocene Basin in Western Hungary. Palaeogeography, Palaeoclimatology, Palaeoecology 88, 25-52. https://doi.org/10.1016/0031-0182(91)90013-h

BERNHARDT B. 1984: A dunántúli-középhegységi eocén szénképzódés fejlödéstörténeti körvonalairól. (Evolution of coal-bearing formations of the Transdanubian Central Range). — Kézirat, Országos Földtani és Geofizikai Adattár, 1-29.

Bernhardt, B., Báldi-Beke, M., Lantos, M., Horváth-Kollányi, K. \& Márton, P. 1988: Eocene magneto- and biostratigraphy at Somlóvásárhely, Hungary. - Acta Geologica Hungarica 31, 33-52.

BetzleR, C., BRACHERT, T. C. \& Nebelsick, J. 1997: The warm temperate carbonate province. A review of the facies, zonations and deliminations. - Cour. Forsch.-Inst. Senckenberg 201, 83-99.

Boda J. \& Monostori M. 1972: Adatok a budai márga képződési körülményeihez. (Contributions to the Formation of the "Buda Marls" [Paleogene]). —Öslénytani Viták 20, 63-70.

Boda J. \& Monostori M. 1973: Üledékmozgási jelenség a budai márgában. (Turbiditic events in the Buda Marl Formation). — Földtani Közlöny 103, 109-201.

Boersma, A., Premoli Silva, I. \& Shackleton, N. J. 1987: Atlantic Eocene planktonic foraminiferal paleohydrographic indicators and stable isotope paleoceanography. — Paleoceanography 2/3, 287-331. https://doi.org/10.1029/pa002i003p00287

Corliss, B. H. \& Emerson, S. 1990: Distribution of Rose Bengal stained deep-sea benthic foraminifera from the Nova Scotian continental margin and Gulf of Maine. — Deep-Sea Research 37, 381-400. https://doi.org/10.1016/0198-0149(90)90015-n

DE RiJk, S., Troelstra, S. R. \& Rohling, E. J. 1999: Benthic foraminiferal distribution in the Mediterranean Sea. - Journal of Foraminiferal Research 29, 93-103. https://doi.org/10.2113/gsjfr.29.2.93

Fodor L., Magyari Á., Fogarasi A. \& Palotás K. 1994: Tercier szerkezetfejlődés és késő paleogén üledékképződés a Budaihegységben. A Budai vonal új értelmezése. (Tertiary tectonics and Late Paleogene sedimentation in the Buda Hills, Hungary. A new interpretation of the Buda Line). — Földtani Közlöny 124, 129-305.

HANTKEN M. 1871: Az esztergomi barnaszénterület földtani viszonyai. (Geology of the brown coal field of Esztergom, Hungary) — Magyar Királyi Földtani Intézet Évkönyve 1871, 3-140.

Hardenbol, J., Thierry, J., Farley, M. B., Jacquin, Th., De Graciansky, P. C. \& Vail, P. R. 1998: Mesozoic and Cenozoic Sequence Chronostratigraphic Framework of European basins. — SEPM Special Publication 60, 1-364. https://doi.org/10.2110/ pec.98.02.0003

HoRVÁTH-KolláNYi K. 1983: Az ÉK-dunántúli terület eocén plankton Foraminifera zónái. (Paleogene plankton foraminifera zonation of NE part of the Transdanubian Central Range). — Földtani Közlöny 113, 225-236.

Horváth-KollánYi K. \& NagY-Gellai, Á. 1989: Palaeobathymetric study of Paleogene profiles upon Foraminifera. — Magyar Állami Földtani Intézet Évi Jelentése 1989/2, 115-131. 
JoRISSEN, F. J. 1987: The Distribution of Benthic Foraminifera in the Adriatic Sea. — Marine Micropaleontology 12, $21-48$. https://doi.org/10.1016/0377-8398(87)90012-0

Jorissen, F. J., DE STIGTER, H. C. \& WidMARK, J. G. V. 1995: A conceptual model explaining benthic foraminiferal microhabitats. Marin Micropaleontology 26, 3-15. https://doi.org/10.1016/0377-8398(95)00047-X

KAIHO, K. 1991: Global changes of Paleogene aerobic/anaerobic benthic foraminifera and deep-sea circulation. — Palaeogeography, Palaeoclimatology, Palaeoecology 83, 65-85. https://doi.org/10.1016/0031-0182(91)90076-4

KAIHO, K. 1994: Benthic foraminiferal dissolved oxygen index and dissolved oxygen levels in the modern ocean. — Geology 22, 719-722. https://doi.org/10.1130/0091-7613(1994)022<0719:bfdoia>2.3.co;2

KAIHO, K. 1999: Effect of organic carbon flux and dissolved oxygen on the benthic foraminiferal oxygen index (BFOI). — Marine Micropaleontology 37, 67-76. https://doi.org/10.1016/s0377-8398(99)00008-0

Kercsmár, Zs., Fodor, L. \& PÁlfalvi, S. 2006: Tectonic control and basin evolution of the Northern Transdanubian Eocene Basins (Vértes Hills, Central Hungary). — Geolines 20, 64-66.

Kercsmár Zs. (szerk.), Budai T., Csillag G., Selmeczi I. \& Sztanó O. 2015: Magyarország felszíni képződményeinek földtana. Magyarázó Magyarország földtani térképéhez (1:500 000). (Surface geology of Hungary. Explanatory notes to the Geological map of Hungary (1: 500 000). — Magyar Földtani és Geofizikai Intézet, Budapest, 1-62.

KolláNyi K., Vetó I. \& HeRTELENDI, E. 1997: Változások a bakonyi eocén tengerben foraminiferák izotóp összetétele tükrében. (Environmental changes in the Eocene sea of the Bakony Mts., Hungary as reflected by isotopic ratios of benthic and planktonic Foraminifera). - Földtani Közlöny 127, 111-126.

KOLLÁNYi K, BERNhARDT B., BÁLDI-BEKE M. \& LANTOS M. 2003: Dunántúli eocén fúrások integrált sztratigráfiai vizsgálata. (Integrated stratigraphic examination of the Eocene boreholes in Transdanubia). — Földtani Közlöny 133, 69-90.

LESS, Gy. 1987: Palaeontology and Stratigraphy of the European Orthophragminae._Geologica Hungarica, series Palaeontologica 51, 1-373.

LUTZE, G. F. 1980: Depth distribution of benthic foraminifera from the continental margin of NW Africa. _ Meteor Forschungsarbeit 32, $31-80$.

Malmgren, A. \& HaQ, B. U. 1982: Assessment of quantitative techniques in Paleobiogeography. — Marine Micropaleontology 31/3, 221-448. https://doi.org/10.1016/0377-8398(82)90003-2

MurRaY, J. W. 1991: Ecology and palaeoecology of benthic foraminifera. — Longman, London, 397 p.

Murray, J. W. 2006: Ecology and Applications of Benthic Foraminifera. — Cambridge University Press, 423 p. https://doi.org/ 10.1017/CBO9780511535529

Nagymarosy, A. 1990a: From Tethys to Paratethys, a way of survival. — Acta Geodaetica, Geophysica et Montanistica Hungarica 25, 373-385.

NAgYmarosy, A. 1990b: Palegeographical and paletectonical outlines of some Intra-Carpathian Paleogene basins. — Geologica Carpathica 41, 259-274.

Nagymarosy, A. \& BÁLdi-Beke, M. 1988: The position of the Paleogene formations of Hungary in the Standard Nannoplankton Zonation. - Annales Universitatis Scientiarum Budapestinensis de Rolando Eötvös nominatae, sectio Geologica 28, 3-25.

OBerhänsli, H., MüLlER-MERZ, E. \& OBERHÄNSLI, R. 1991: Eocene paleoceanographic evolution at 20-30 S in the Atlantic Ocean. Palaeogeography, Palaeoclimatology, Palaeoecology 83, 173-215. https://doi.org/10.1016/0031-0182(91)90079-7

OzSVÁRT, P. 1999: Middle Eocene foraminifer, mollusc and ostracod fauna from the Csordakút Basin (Gerecse Mountains, Hungary): palaeoenviroments recorded in a transgressive sequence. - Annales Universitatis Scientiarum Budapestinensis, sectio Geologica 32, 73-135.

OzSVÁRT P. 2003: A magyarországi paleogén medence paleo-oceanográfiája bentosz foraminiferák ökológiai vizsgálata alapján. (Paleoceanographic history of the Hungarian Paleogene Basin by paleoecological analysis of benthic foraminifera). - $\mathrm{PhD}$ értekezés, ELTE Őslénytani Tanszék, (PhD thesis, ELTE, Department of Palaeontology), Budapest, 182 p.

OzsvárT, P. 2007: Middle and Late Eocene Benthic foraminiferal fauna of the Hungarian Paleogene Basin: systematics and paleoecology. - Geologica Pannonica, Special Publication 2, 1-127.

Ozsvárt, P., Kocsis, L., Nyerges, A., GYőRI, O. \& PÁLFy, J. 2016: The Eocene-Oligocene climate transition in the Central Paratethys. Palaeogeography, Palaeoclimatology, Palaeoecology 459, 471-487. https://doi.org/10.1016/j.palaeo.2016.07.034

PODANI J. 1997: Bevezetés a sokváltozós biológiai adatfeltárás rejtelmeibe. (Introduction to the analysis of multivariate biological data). - Scientia, Budapest, 412 p.

Royden, L. \& Horváth, F. (eds) 1998: The Pannonian Basin — a Study in Basin Evolution. — AAPG Memoire 45, 394 p. https://doi.org/ 10.1306/0c9b249d-1710-11d7-8645000102c1865d

Scherbacher, M., Schmiedl, G., \& Hemleben, Ch. 2001: Early Oligocene benthic Foraminifera from the Lower Inn Valley area: implications for the paleoenvironmental evolution of the Inneralpine Molasse. — In: PILLER, E. \& RASSER, M., W. (eds): Paleogene of the Eastern Alps. - Österr. Akad. Wiss., Schriftenr. Erdwiss. Komm, 14, 611-640.

Schmiedl, G., Scherbacher, M., Bruch, A. A., Jelen, B., Nebelsick, J. Hemleben, Ch., Mosbrugger, V. \& Rifel, H: 2002: Paleoenvironmental evolution of the Paratethys in the Slovenian Basin during the Late Paleogene. - International Journal of Earth Sciences 91, 123-132. https://doi.org/10.1007/s005310000118

Sen Gupta, B. K. \& Machian-Castillo, M. L. 1993: Benthic foraminifera in oxygen poor habitats. — Marine Micropaleontology 20, 183-201. https://doi.org/10.1016/0377-8398(93)90032-s

Sgarrella, F. \& Montcharmont Zei, M. 1993: Benthic foraminifera of the Gulf of Naples (Italy): Systematic and autecology. — Bolletino Soc. Paleontologia Italiana 32, 145-246.

SzTANó O. \& FodOR L. 1997: Lejtőüledékek a paleogén medence peremén: A felső-eocén Piszkei Márga (Nyergesújfalu, Sánc-hegy) ülepedési és szerkezeti viszonyai. (Bathyal slope deposits in the Paleogene Basin: A case study of the Upper Eocene Piszke Marl (Nyergesújfalu, Sánc Hill, Hungary). — Földtani Közlöny 127, 267-290. 
TARI G. 1994: Alpine tectonics of the Pannonian Basin. — PhD értekezés, Rice University, Houston, 501 p.

TeLEGDI-Roth K. 1927: Infraoligocén denudáció nyomai a Dunántúli-Középhegység északnyugati peremén. (Tracing of infraoligocene denudation in NW part of Transdanubian Central Range). — Földtani Közlöny 57, 117-128.

VARGa P. 1985: Mészturbidites betelepülesek a Budai Márgában és a Tardi Agyagban. (Turbiditic limestone intercalations of the Buda Marl and Tard Clay). — Óslénytani Viták 31, 93-99.

Vetó, I., Ozsvárt, P., Futó, I. \& HetÉnyi, M., 2007: Extension of carbon flux estimation to oxic sediments based on sulphur geochemistry and analysis of benthic foraminiferal assemblages: a case history from the Eocene of Hungary. — Palaeogeography, Palaeoclimatology, Palaeoecology 248, 119-144. https://doi.org/10.1016/j.palaeo.2006.12.001

VogL, M. 1910: A piszkei bryozoás márga faunája. (Fossils of Bryozoan Marl from Piszke). — A Magyar Királyi Földtani Intézet Évkönyve 18, 175-204.

VöRÖS A. 1989: Middle Eocene transgression and basin evolution in the Transdanubian Central Range, Hungary: sedimentological contributions. - Fragmenta Mineralogica et Paleontologica 14, 63-72.

WAdE, B. S. \& Kroon, D: 2002: Middle Eocene regional climate instability: Evidence from the western North Atlantic. - Geology 30, 1011-1014. https://doi.org/10.1130/0091-7613(2002)030<1011:mercie>2.0.co;2

Kézirat beérkezett: 2018. 04.26. 